\title{
First assessment of the earth heat inventory within CMIP5 historical simulations
}

\author{
Francisco José Cuesta-Valero ${ }^{1,2}$, Almudena García-García ${ }^{1,3}$, Hugo Beltrami ${ }^{1}$, and Joel Finnis ${ }^{4}$ \\ ${ }^{1}$ Climate \& Atmospheric Sciences Institute, St. Francis Xavier University, Antigonish, NS, Canada \\ ${ }^{2}$ Environmental Sciences Program, Memorial University of Newfoundland, St. John's, NL, Canada \\ ${ }^{3}$ Department of Remote Sensing, Helmholtz Centre for Environmental Research-UFZ, Leipzig, Germany \\ ${ }^{4}$ Department of Geography, Memorial University of Newfoundland, St. John's, NL, Canada
}

Correspondence: Hugo Beltrami (hugo@stfx.ca)

Received: 3 December 2020 - Discussion started: 28 December 2020

Accepted: 1 April 2021 - Published: 10 May 2021

\begin{abstract}
The energy imbalance at the top of the atmosphere over the last century has caused an accumulation of heat within the ocean, the continental subsurface, the atmosphere and the cryosphere. Although $\sim 90 \%$ of the energy gained by the climate system has been stored in the ocean, the other components of the Earth heat inventory cannot be neglected due to their influence on associated climate processes dependent on heat storage, such as sea level rise and permafrost stability. However, there has not been a comprehensive assessment of the heat inventory within global climate simulations yet. Here, we explore the ability of 30 advanced general circulation models (GCMs) from the fifth phase of the Coupled Model Intercomparison Project (CMIP5) to simulate the distribution of heat within the Earth's energy reservoirs for the period 1972-2005 of the Common Era. CMIP5 GCMs simulate an average heat storage of $247 \pm 172 \mathrm{ZJ}$ (96 $\pm 4 \%$ of total heat content) in the ocean, $5 \pm 9 \mathrm{ZJ}(2 \pm 3 \%)$ in the continental subsurface, $2 \pm 3 \mathrm{ZJ}(1 \pm 1 \%)$ in the cryosphere and $2 \pm 2 \mathrm{ZJ}(1 \pm$ $1 \%$ ) in the atmosphere. However, the CMIP5 ensemble overestimates the ocean heat content by $83 \mathrm{ZJ}$ and underestimates the continental heat storage by $9 \mathrm{ZJ}$ and the cryosphere heat content by $5 \mathrm{ZJ}$, in comparison with recent observations. The representation of terrestrial ice masses and the continental subsurface, as well as the response of each model to the external forcing, should be improved in order to obtain better representations of the Earth heat inventory and the partition of heat among climate subsystems in global transient climate simulations.
\end{abstract}

\section{Introduction}

Sustained net radiative imbalance at the top of the atmosphere is increasing the heat stored within the climate subsystems - the ocean, the continental subsurface, the atmosphere and the cryosphere (Hansen et al., 2011; von Schuckmann et al., 2020). The ocean is the largest component of the Earth heat inventory (EHI), accounting for around $90 \%$ of the total heat in the climate system (Rhein et al., 2013; Gleckler et al., 2016; von Schuckmann et al., 2020). Nonetheless, it is imperative to measure the distribution of heat storage within the four components of the climate system, since the evolution of several physical processes critical to understanding climate change and quantifying future impacts of climate change on society is strongly dependent on the partition of heat among all climate components.

The evolution of ocean heat content determines the thermosteric component of sea level rise (Church et al., 2011; Kuhlbrodt and Gregory, 2012; Levitus et al., 2012), affects the total precipitation and intensity of hurricanes (Mainelli et al., 2008; Wada and Chan, 2008; Lin et al., 2013; Trenberth et al., 2018), and influences regional cyclonic activity (Bhowmick et al., 2016). The increase in ground heat content leads to the warming of the continental subsurface and to permafrost thawing in the Northern Hemisphere (Koven et al., 2013; Cuesta-Valero et al., 2016; McGuire et al., 2018; Biskaborn et al., 2019; Hock et al., 2019; Meredith et al., 2019; Soong et al., 2020). Thus, the increase in continental heat 
storage threatens the stability of the global soil carbon pool, potentially facilitating the release of large amounts of greenhouse gasses from the decomposition of soil organic matter in northern soils (Koven et al., 2011; MacDougall et al., 2012; Schädel et al., 2014; Schuur et al., 2015; Hicks Pries et al., 2017; McGuire et al., 2018). Melting of ice sheets in Greenland and Antarctica as well as glacier degradation at all latitudes contribute to sea level rise (Jacob et al., 2012; Hanna et al., 2013; Vaughan et al., 2013; Dutton et al., 2015; Bamber et al., 2018; King et al., 2018; Rignot et al., 2019; Hock et al., 2019; Oppenheimer et al., 2019; Meredith et al., 2019; Zemp et al., 2019) and, together with changes in the extension and volume of sea ice, may disturb deep water formation zones and alter ocean circulation and large-scale heat distribution (Hu et al., 2013; Jahn and Holland, 2013; Ferrari et al., 2014; Smeed et al., 2018; Collins et al., 2019). The evolution of the atmosphere heat content constrains the projected change in total global precipitation due to atmospheric warming (Pendergrass and Hartmann, 2014a; Hegerl et al., 2015), and the additional moisture in a warmer atmosphere increases the frequency of extreme precipitation events (Pendergrass and Hartmann, 2014b). The intensity of cyclones and hurricanes is also expected to increase in the future due to the higher energy available in the atmosphere (Pan et al., 2017).

Therefore, the partition of heat within these subsystems has long-term impacts on society, as the heat content of each subsystem is related to processes altering near-surface conditions. Higher surface temperatures together with changes in precipitation regimes and sea level rise threaten global food security (Lloyd et al., 2011; Rosenzweig et al., 2014; Phalkey et al., 2015; Campbell et al., 2016) and may result in an increase in the frequency of floods and storm surges (McGranahan et al., 2007; Lin et al., 2013; Kundzewicz et al., 2014). The combination of high temperatures, high levels of moisture and changes in precipitation patterns also affect human health, particularly for the populations least responsible for climate change (Patz et al., 2007). These changes in nearsurface conditions increase the risk of high levels of heat stress (Sherwood and Huber, 2010; Matthews et al., 2017) and the spread of infectious diseases (Levy et al., 2016; Wu et al., 2016; McPherson et al., 2017), among other risks for human health (McMichael et al., 2006).

General circulation model (GCM) simulations are the main source of information about the possible evolution of the climate system, which is critical for society's adaptation to future risks posed by climate change. Modelling experiments performed for the fifth phase of the Coupled Model Intercomparison Project (CMIP5) have provided several insights into the long-term evolution of the net radiative imbalance at the top of the atmosphere (Allan et al., 2014; Smith et al., 2015), the evolution of ocean heat content since preindustrial times (Gleckler et al., 2016) and the relationship between these two magnitudes (Palmer et al., 2011; Palmer and McNeall, 2014; Smith et al., 2015). The same GCM simula- tions, nevertheless, do not simulate other aspects of the Earth heat inventory successfully. CMIP5 simulations are unable to accurately represent heat storage within the continental subsurface over the second half of the 20th century (CuestaValero et al., 2016), and many do not conserve atmospheric water (Liepert and Lo, 2013) or subsurface water (Krakauer et al., 2013; Trenberth et al., 2016) and do not conserve the total heat in the system (Hobbs et al., 2016). Furthermore, there has not yet been an assessment of the ability of CMIP5 GCMs to reproduce heat storage within the atmosphere and the cryosphere, despite their impact on a variety of phenomena of critical interest to both society and the scientific community.

Here, we assess the ability of 30 CMIP5 GCM "Historical" simulations to reproduce the Earth heat inventory and the partition of heat within the ocean, continental subsurface, atmosphere and cryosphere. Results are compared with observations for the period 1972-2005 of the Common Era (CE). Our analysis reveals the importance of the simulated terrestrial ice masses and the represented continental subsurface volume for achieving a realistic distribution of the total Earth heat content within GCM simulations, and it reinforces the need to reduce the spread in model responses to external forcing.

\section{Data and methods}

A total of 30 Historical simulations performed with advanced general circulation models were retrieved from the fifth phase of the Coupled Model Intercomparison Project (CMIP5) archive (Taylor et al., 2011). Historical simulations attempt to represent the evolution of global climate from the Industrial Revolution to the present (18502005 CE) using estimates of natural and anthropogenic emissions of greenhouse gases and aerosols, as well as changes in land cover and land use (Mieville et al., 2010; Hurtt et al., 2011). We analysed the simulated evolution of heat storage in the entire climate system and in the different subsystems (the ocean, continental subsurface, atmosphere and cryosphere) for the period 1972-2005 CE, in common with observations.

Estimates of the Earth heat inventory from observations are retrieved from Church et al. (2011) and von Schuckmann et al. (2020). Results in Church et al. (2011) are provided for the period 1972-2008 CE; thus we scale those estimates linearly to cover the period 1972-2005 CE, in common with CMIP5 Historical simulations. Observational estimates from 1960 to $2018 \mathrm{CE}$ at annual resolution are taken from von Schuckmann et al. (2020); thus results for the period 1972-2005 CE are selected without scaling or modification. Both datasets employ similar measurements from mechanical and expendable bathythermographs to estimate the heat content within the ocean. Differences in the reported heat storage are caused by the statistical treatment of data gaps, the choice of the climatology, the approach to account 
for instrumental biases, and the higher number of recent measurements included in von Schuckmann et al. (2020). Church et al. (2011) extrapolates the continental heat storage estimated in Huang (2006) from meteorological observations of surface air temperature at $2 \mathrm{~m}$. Otherwise, von Schuckmann et al. (2020) include ground heat content estimates from an updated database of borehole temperature profile measurements (Cuesta-Valero et al., 2021). This method contrasts to the one included in Church et al. (2011), since estimates of continental heat storage are retrieved from direct measurements of subsurface temperatures. There are substantial differences between both datasets in the methods employed to obtain the heat storage in the atmosphere. Church et al. (2011) estimates heat storage as proportional to the change in surface air temperature, while von Schuckmann et al. (2020) considers the atmospheric profile in several reanalysis products, multisatellite radio occultation records and radiosonde observations (Steiner et al., 2020), analysing temperature, water content and wind intensity. Estimates of ice melting from glaciers and ice sheets are considered in both datasets, with more recent analyses included in von Schuckmann et al. (2020). Changes in sea ice volume in Church et al. (2011) are obtained from Levitus et al. (2005), and from the PanArctic Ice Ocean Modeling and Assimilation System (PIOMAS, Zhang and Rothrock, 2003; Schweiger et al., 2019) in the case of von Schuckmann et al. (2020). All changes in ice mass are multiplied by the latent heat of fusion in order to obtain the corresponding estimate of cryosphere heat content.

Global averages of ocean heat content (OHC), the heat content within the continental subsurface (ground heat content, GHC), atmosphere heat content (AHC) and heat uptake by ice masses (cryosphere heat content, $\mathrm{CHC}$ ) were derived from the CMIP5 Historical experiments. The OHC values were estimated using the formulation for potential enthalpy described in McDougall (2003) and Griffies (2004) from simulated seawater potential temperature and salinity profiles (Table 1 contains the list of variables employed for estimating each term of the EHI). Once the potential enthalpy has been determined, estimates of seawater density (McDougall et al., 2003) and pressure profiles (Smith et al., 2010) allowed simulated heat content in the ocean to be calculated as follows:

$Q_{\text {Ocean }}=\sum_{i=z_{0}}^{z_{\mathrm{f}}} \rho_{i}\left(S, \theta, p\left(z_{i}\right)\right) \cdot \mathcal{H}_{i}^{\mathrm{o}}(S, \theta) \cdot \Delta z_{i}$,

where $Q_{\text {Ocean }}$ is the ocean heat per surface unit $\left(\right.$ in $\mathrm{J} \mathrm{m}^{-2}$ ); $S$ is salinity (in psu); $\theta$ is potential temperature (in ${ }^{\circ} \mathrm{C}$ ); $p$ is pressure (in bar); and $z_{i}, \rho_{i}, \mathcal{H}_{i}^{\mathrm{o}}$ and $\Delta z_{i}$ are depth (in m), density (in $\mathrm{kg} \mathrm{m}^{-3}$ ), potential enthalpy (in $\mathrm{J} \mathrm{kg}^{-1}$ ) and thickness (in $\mathrm{m}$ ) of the $i$ th ocean layer, respectively. This approach is based on the availability of both temperature and salinity profiles in CMIP5 simulations, which allows changes in water density to be integrated. Estimates of OHC from observa- tional methods only consider temperature profiles, as salinity profiles are not routinely measured at the global scale. However, CMIP5 simulations yield similar changes in OHC from both methods (Fig. S1 in the Supplement). Thus, we use the method described by Eq. (1) to estimate OHC from simulations, since this approach includes simulated salinity profiles in the analysis, maximizing the information considered to estimate heat content.

The GHC series were estimated as in Cuesta-Valero et al. (2016) for all terrestrial grid cells. Subsurface thermal properties were computed taking into account spatial variations in soil composition (percentage of sand, clay and bedrock) and simulated subsurface water and ice amounts (Van Wijk et al., 1963; Oleson et al., 2010). The subsurface temperature profile was then integrated following

$$
Q_{\text {Ground }}=\sum_{i=z_{0}}^{z_{\mathrm{f}}} \rho C_{i} \cdot T_{i} \cdot \Delta z_{i}
$$

where $Q_{\text {Ground }}$ is the subsurface heat storage per surface unit (in $\mathrm{J} \mathrm{m}^{-2}$ ), and $\rho C_{i}, T_{i}$ and $\Delta z_{i}$ are the volumetric heat capacity (in $\mathrm{J} \mathrm{m}^{-3} \mathrm{~K}^{-1}$ ), the temperature (in $\mathrm{K}$ ) and the thickness (in $\mathrm{m}$ ) of the $i$ th soil layer, respectively. All CMIP5 GCMs present outputs for subsurface temperature, but not all models provide outputs for subsurface water and ice content in the same format (Table 1), hampering the estimate of thermal properties $(\rho C)$ in Eq. (2). Indeed, two-thirds of the GCMs provide the joint content of water and ice for each soil layer (mrlsl variable in CMIP5 notation), while the remaining third provides the total water and ice content in the entire soil column (mrso variable). As in Cuesta-Valero et al. (2016), we considered water to be frozen in layers with temperatures below $0{ }^{\circ} \mathrm{C}$ and liquid water otherwise for models providing the mrlsl variable. For models providing the mrso variable, we distributed the water and ice content among the soil layers proportionally with layer thickness, considering ice in soil layers with temperature below $0^{\circ} \mathrm{C}$ and liquid water otherwise.

The AHC series from CMIP5 simulations were estimated using the theoretical foundations of Trenberth (1997) and Previdi et al. (2015). The simulated air temperature profile was integrated for all atmospheric grid cells together with estimates of wind kinetic energy, latent heat of vaporization and surface geopotential, which was determined as in Dutton (2002). Vertical atmospheric profiles were integrated in pressure coordinates as follows:

$Q_{\text {Atmosphere }}=\frac{1}{g} \sum_{i=0}^{p_{\mathrm{s}}}\left(c_{\mathrm{p}} \cdot T_{i}+k_{i}+L \cdot q_{i}+\Phi_{\mathrm{s}}\right) \cdot \Delta p_{i}$,

where $Q_{\text {Atmosphere }}$ is atmospheric heat per surface unit (in $\mathrm{J} \mathrm{m}^{-2}$ ); $g$ is apparent acceleration due to gravity (in $\mathrm{m} \mathrm{s}^{-2}$ ); $p_{\mathrm{s}}$ is surface pressure (in $\mathrm{Pa}$ ); $c_{\mathrm{p}}=$ $1000 \mathrm{~J} \mathrm{~kg}^{-1} \mathrm{~K}^{-1}$ is the specific heat of air at constant pressure; $L=2260 \mathrm{~J} \mathrm{~kg}^{-1}$ is the latent heat of vaporization; 
Table 1. Variables from the CMIP5 archive employed to estimate the heat content within each climate subsystem by each GCM (Sect. 2). References for each GCM Historical experiment are also provided. All variables correspond with the rli1p1 realization of the Historical experiment. A description of all listed variables can be found at the dedicated web page of the Lawrence Livermore National Laboratory (LLNL, 2010).

\begin{tabular}{|c|c|c|c|c|c|c|}
\hline Model & Ocean & Land & Atmosphere & Cryosphere & $\begin{array}{l}\text { TOA } \\
\text { imbalance }\end{array}$ & References \\
\hline CCSM4 & so, thetao & mrlsl, tsl & hus, ps, ta, ua, va & mrfso, sic, sit, snw & rlut, rsdt, rsut & Gent et al. (2011) \\
\hline CESM1-BGC & so, thetao & mrlsl, tsl & hus, ps, ta, ua, va & mrfso, sic, sit, snw & rlut, rsdt, rsut & Long et al. (2013) \\
\hline CESM1-CAM5 & so, thetao & mrlsl, tsl & hus, ps, ta, ua, va & mrfso, sic, sit, snw & rlut, rsdt, rsut & Meehl et al. (2013) \\
\hline CESM1-FASTCHEM & so, thetao & mrlsl, tsl & hus, ps, ta, ua, va & mrfso, sic, sit, snw & rlut, rsdt, rsut & Hurrell et al. (2013) \\
\hline CESM1-WACCM & so, thetao & mrlsl, tsl & hus, ps, ta, ua, va & mrfso, sic, sit, snw & rlut, rsdt, rsut & Marsh et al. (2013) \\
\hline NOR-ESM1-M & so, thetao & mrlsl, tsl & hus, ps, ta, ua, va & mrfso, sic, sit, snw & rlut, rsdt, rsut & Iversen et al. (2013) \\
\hline NOR-ESM1-ME & so, thetao & mrlsl, tsl & hus, ps, ta, ua, va & mrfso, sic, sit, snw & rlut, rsdt, rsut & Tjiputra et al. (2013) \\
\hline INM-CM4 & so, thetao & mrlsl, tsl & hus, ps, ta, ua, va & sic, sit, snw & rlut, rsdt, rsut & Volodin et al. (2010) \\
\hline MIROC-ESM & so, thetao & mrlsl, tsl & hus, ps, ta, ua, va & mrfso, sic, sit, snw & rlut, rsdt, rsut & Watanabe et al. (2011) \\
\hline MIROC-ESM-CHEM & so, thetao & mrlsl, tsl & hus, ps, ta, ua, va & mrfso, sic, sit, snw & rlut, rsdt, rsut & Watanabe et al. (2011) \\
\hline MIROC5 & so, thetao & mrlsl, tsl & hus, ps, ta, ua, va & mrfso, sic, sit, snw & rlut, rsdt, rsut & Watanabe et al. (2010) \\
\hline GFDL-CM3 & so, thetao & mrlsl, tsl & hus, ps, ta, ua, va & mrfso, sic, sit, snw & rlut, rsdt, rsut & Donner et al. (2011) \\
\hline GFDL-ESM2G & so, thetao & mrlsl, tsl & hus, ps, ta, ua, va & mrfso, sic, sit, snw & rlut, rsdt, rsut & Dunne et al. (2012) \\
\hline GFDL-ESM2M & so, thetao & mrlsl, tsl & hus, ps, ta, ua, va & mrfso, sic, sit, snw & rlut, rsdt, rsut & Dunne et al. (2012) \\
\hline MRI-CGCM3 & so, thetao & mrso, tsl & hus, ps, ta, ua, va & mrfso, sic, sit, snw & rlut, rsdt, rsut & Yukimoto et al. (2012) \\
\hline MRI-ESM1 & so, thetao & mrso, tsl & hus, ps, ta, ua, va & mrfso, sic, sit, snw & rlut, rsdt, rsut & Adachi et al. (2013) \\
\hline MPI-ESM-LR & so, thetao & mrso, tsl & hus, ps, ta, ua, va & sic, sit, snw & rlut, rsdt, rsut & Giorgetta et al. (2013) \\
\hline MPI-ESM-MR & so, thetao & mrso, tsl & hus, ps, ta, ua, va & sic, sit, snw & rlut, rsdt, rsut & Giorgetta et al. (2013) \\
\hline MPI-ESM-P & so, thetao & mrso, tsl & hus, ps, ta, ua, va & sic, sit, snw & rlut, rsdt, rsut & Jungclaus et al. (2014) \\
\hline CMCC-CM & so, thetao & mrso, tsl & hus, ps, ta, ua, va & sic, sit, snw & rlut, rsdt, rsut & Scoccimarro et al. (2011) \\
\hline CMCC-CMS & so, thetao & mrso, tsl & hus, ps, ta, ua, va & sic, sit, snw & rlut, rsdt, rsut & Scoccimarro et al. (2011) \\
\hline CANESM2 & so, thetao & mrlsl, tsl & hus, ps, ta, ua, va & mrfso, sic, sit, snw & rlut, rsdt, rsut & Arora et al. (2011) \\
\hline IPSL-CM5A-LR & so, thetao & mrso, tsl & hus, ps, ta, ua, va & sic, sit & rlut, rsdt, rsut & Dufresne et al. (2013) \\
\hline IPSL-CM5A-MR & so, thetao & mrso, tsl & hus, ps, ta, ua, va & sic, sit & rlut, rsdt, rsut & Dufresne et al. (2013) \\
\hline IPSL-CM5B-LR & so, thetao & mrso, tsl & hus, ps, ta, ua, va & sic, sit & rlut, rsdt, rsut & Dufresne et al. (2013) \\
\hline GISS-E2-H & so, thetao & mrlsl, tsl & hus, ps, ta, ua, va & mrfso, sic, sit, snw & rlut, rsdt, rsut & Miller et al. (2014) \\
\hline GISS-E2-R & so, thetao & mrlsl, tsl & hus, ps, ta, ua, va & mrfso, sic, sit, snw & rlut, rsdt, rsut & Miller et al. (2014) \\
\hline BCC-CSM1.1 & so, thetao & mrlsl, tsl & hus, ps, ta, ua, va & mrfso, sic, sit, snw & rlut, rsdt, rsut & Wu et al. (2014) \\
\hline BCC-CSM1.1-M & so, thetao & mrlsl,tsl & hus, ps, ta, ua, va & mrfso, sic, sit, snw & rlut, rsdt, rsut & Wu et al. (2014) \\
\hline HADGEM2-CC & so, thetao & mrlsl, tsl & hus, ps, ta, ua, va & mrfso, sic, sit, snw & rlut, rsdt, rsut & Collins et al. (2011) \\
\hline
\end{tabular}

$\Phi_{\mathrm{S}}$ is the surface geopotential estimated from orography (in $\mathrm{m}^{2} \mathrm{~s}^{-2}$ ); and $T_{i}, k_{i}, q_{i}$ and $\Delta p_{i}$ are the air temperature (in $\mathrm{K}$ ), specific kinetic energy (in $\mathrm{J} \mathrm{kg}$ ), specific humidity (in $\mathrm{kg} \mathrm{kg}^{-1}$ ) and thickness (in $\mathrm{Pa}$ ) of the $i$ th atmospheric layer, respectively.

For estimating the CHC series, the simulated cryosphere was divided into three terms: sea ice, subsurface ice and glaciers. Variations in the mass of simulated sea ice and subsurface ice were multiplied by the latent heat of fusion $\left(L_{\mathrm{f}}=3.34 \times 10^{5} \mathrm{~J} \mathrm{~kg}^{-1}\right.$; Rhein et al., 2013) to obtain the heat absorbed in the melting process. The same method was applied to the change in snow mass in grid cells containing land ice within each CMIP5 GCM (glaciers or ice sheets, sftgif variable in the CMIP5 archive). Although this is not a satisfactory approach given the differences between snow and land ice, it is the only available approximation since CMIP5 GCMs do not typically represent terrestrial ice masses (Flato et al., 2013). Therefore, the cryosphere heat content was estimated as

$Q_{\text {Cryosphere }}=L_{\mathrm{f}} \cdot(\Delta \omega+\rho \cdot \Delta p \cdot \Delta z+\Delta \Omega)$,

where $Q_{\text {Cryosphere }}$ is absorbed heat per surface unit (in $\mathrm{J} \mathrm{m}^{-2}$ ), $\rho=920 \mathrm{~kg} \mathrm{~m}^{-3}$ is ice density (Rhein et al., 2013), $\Delta \omega$ is the change in subsurface ice mass per surface unit (in $\mathrm{kg} \mathrm{m}^{-2}$ ), $\Delta p$ is the change in the proportion of sea ice at each ocean grid cell, $\Delta z$ is the change in thickness of sea ice at each ocean grid cell (in $\mathrm{m}$ ), and $\Delta \Omega$ is the change in snow amount at each cell containing land ice (in $\mathrm{kg} \mathrm{m}^{-2}$ ). It is important to note that nine of the CMIP5 GCMs did not provide outputs for the subsurface ice amount (mrfso variable) and that three of the models did not provide outputs for snow amount (snw variable; see Table 1), and thus these terms are missing in the $\mathrm{CHC}$ estimates from those models. We were unable to retrieve the file indicating the cells con- 
taining land ice (sftgif file) for the HADGEM2-CC GCM; thus we used the CMCC-CMS sftgif file interpolated to the HADGEM2-CC grid, since the grid for both models have a similar spatial resolution $\left(1.25^{\circ} \times 1.875^{\circ}\right.$ for HADGEM2$\mathrm{CC} ; 1.875^{\circ} \times 1.875^{\circ}$ for $\left.\mathrm{CMCC}-\mathrm{CMS}\right)$.

Estimates of total heat in the climate system from each CMIP5 model are required to determine the simulated partition of heat among each climate subsystem. The total heat content can be determined as the sum of the heat storage within the different climate subsystems (Earth heat content, EHC) or as the integration of the radiative imbalance at the top of the atmosphere $(\mathrm{N})$ during the period of interest. Both approximations have been used in the literature and are considered equivalent (Rhein et al., 2013; Palmer and McNeall, 2014; Trenberth et al., 2014; von Schuckmann et al., 2016). That is, if a model does not produce artificial sources or leakages of energy or mass (i.e. if the model conserves the total heat content in the system), the change in $\mathrm{N}$ and in EHC should be almost identical (Hobbs et al., 2016). Nevertheless, CMIP5 GCM simulations are prone to drift, particularly the ocean component due to incomplete model spin-up procedures (Sen Gupta et al., 2013; Séférian et al., 2016). For this reason, potential drifts in estimates of heat content and the components of the radiative budget at the top of the atmosphere were removed by subtracting the linear trend of the corresponding preindustrial control simulation from the Historical simulations, which should correct artificial drifts in the simulated heat content within each climate subsystem (Hobbs et al., 2016). $\mathrm{N}$ estimates from the CESM1-CAM5 GCM constitute a particular case, since an unrealistic trend remained in the Historical experiment in comparison with other CMIP5 GCMs after removing the drift using data from the corresponding control simulation (Fig. S2). The rest of the variables from this GCM were dedrifted using the trend estimated from the preindustrial control simulation as in the other CMIP5 simulations, but the drift in the outgoing shortwave radiation and the outgoing longwave radiation at the top of the atmosphere could not be removed. Therefore, we used the trend estimated from the first five decades of the Historical simulation (1861-1911 CE) to remove the drift in $\mathrm{N}$ estimates, achieving a better comparison with the other CMIP5 GCMs (Fig. S2).

As a complement to the estimates of the EHI detailed above, we also estimated the partition of the simulated total heat content among the ocean, the continental subsurface, the atmosphere and the cryosphere. A linear regression analysis was performed between the evolution of the simulated heat storage within each climate subsystem and the estimates of total heat content in the entire climate system to determine the partition of heat within the four climate subsystems (Fig. 1). The slope of the linear fit was assumed to represent the simulated proportion of heat in the corresponding subsystem, thus providing estimates of $\mathrm{OHC} / \mathrm{N}$ and $\mathrm{OHC} / \mathrm{EHC}$ for the simulated proportion of heat in the ocean, GHC / N and GHC / EHC for the simulated proportion of heat in the

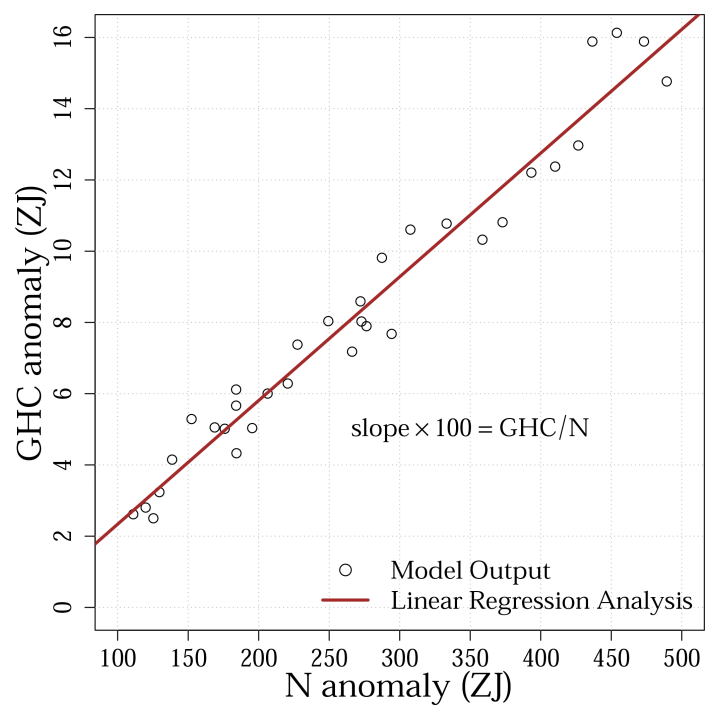

Figure 1. Example to illustrate the process to estimate heat proportions using data from the CCSM4 Historical simulation. In this case, the proportion of heat within the continental subsurface (GHC / N) is estimated as the slope from the linear regression analysis (solid line) between the simulated GHC and $\mathrm{N}$ anomalies (dots) for the period 1972-2005 CE multiplied by 100 . The proportion of heat in the rest of the climate subsystems is estimated by replacing the GHC anomaly with the corresponding heat content anomaly. The EHC anomaly is also used as the metric for the total heat content in the system by replacing the $\mathrm{N}$ anomaly in the regression analysis.

continental subsurface, $\mathrm{AHC} / \mathrm{N}$ and $\mathrm{AHC} / \mathrm{EHC}$ for the simulated proportion of heat in the atmosphere, and $\mathrm{CHC} / \mathrm{N}$ and $\mathrm{CHC} / \mathrm{EHC}$ for the simulated proportion of heat absorbed by the cryosphere.

\section{Results}

\subsection{Earth heat inventory}

The CMIP5 ensemble mean overestimates the observed ocean heat content for the period 1972-2005 CE and underestimates the observations for the continental subsurface and the cryosphere (Fig. 2). Additionally, the multimodel mean yields higher total heat in the climate system than observations, as expected due to the high $\mathrm{OHC}$ values reached by these simulations (Fig. 2a). Indeed, the CMIP5 multimodel mean yields an $\mathrm{OHC}$ increase of $247 \pm 172 \mathrm{ZJ}$ (mean $\pm 2 \mathrm{SD}$ (standard deviations), $1 \mathrm{ZJ}=1 \times 10^{21} \mathrm{~J}$ ) for $1972-2005 \mathrm{CE}$, higher than the observational estimates in Church et al. (2011) ( 199 ZJ) and von Schuckmann et al. (2020) (164 \pm $17 \mathrm{ZJ}$, Table 2). These high OHC estimates are the cause of the large Earth heat content displayed by the CMIP5 ensemble, since the EHC estimates result from the cumulative heat storage in the four climate subsystems, and the ocean accounts for around $90 \%$ of the total heat storage (Church et al., 2011; Hansen et al., 2011; Rhein et al., 2013; Gleck- 

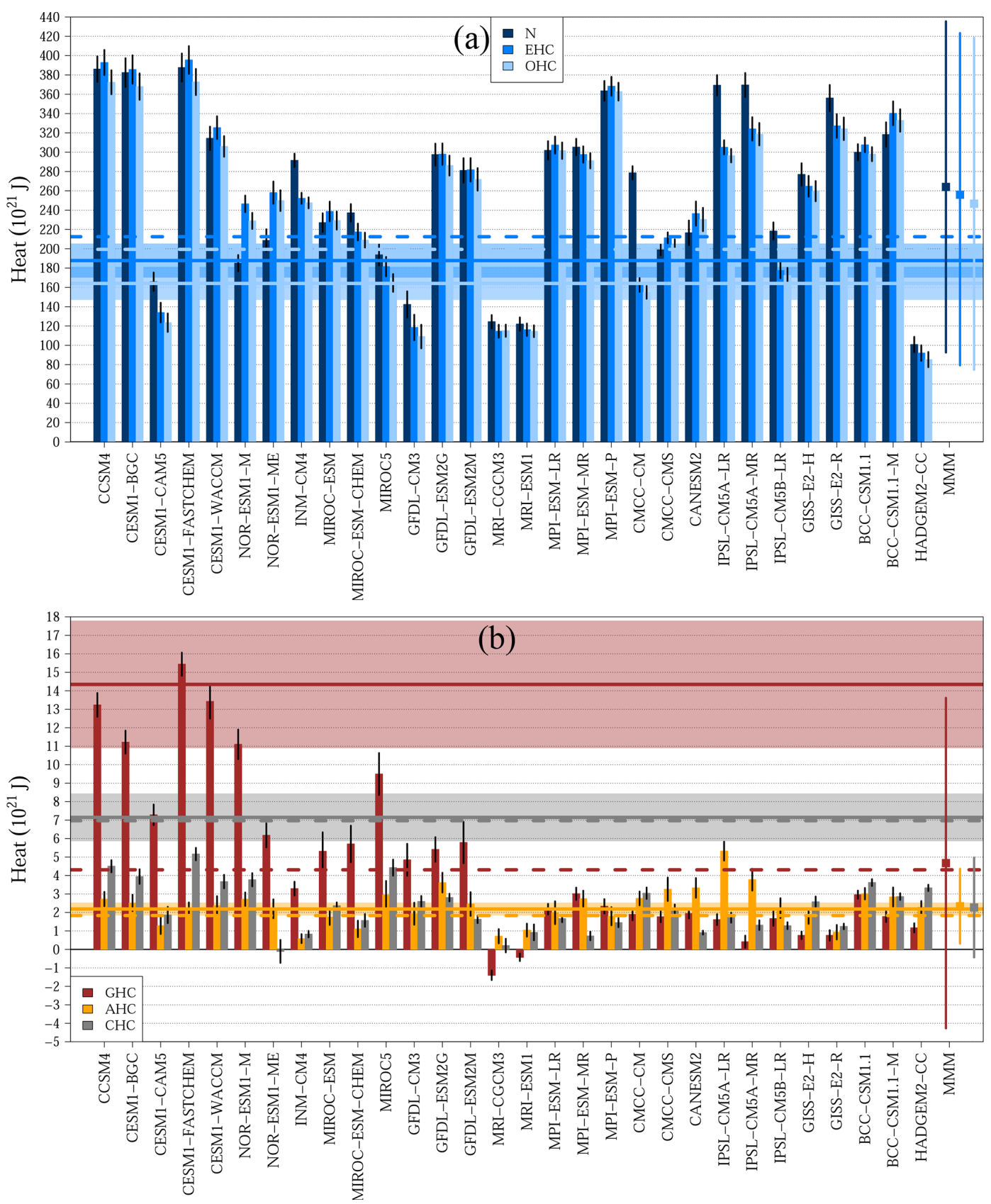

Figure 2. Simulated heat storage for 1972-2005 CE from 30 CMIP5 GCM Historical simulations. (a) Results for N (dark blue bars), EHC (blue bars) and OHC (light blue bars). (b) Results for GHC (brown bars), AHC (orange bars) and CHC (grey bars). Vertical black lines at the top of the bars indicate the $95 \%$ confidence interval for each model. Observations from von Schuckmann et al. (2020) are shown as solid horizontal lines and shadows (mean and $95 \%$ confidence intervals), and observations from Church et al. (2011) are displayed as dashed horizontal lines. Multimodel means and $95 \%$ confidence intervals are indicated in the right side of the panel (MMM).

ler et al., 2016; von Schuckmann et al., 2020). The integration of the radiative imbalance at the top of the atmosphere for the period 1972-2005 CE should yield similar values to those of EHC and OHC over the same period, as the radiative imbalance causes the heat storage within the different climate subsystems. Indeed, EHC and OHC estimates are generally similar within each model, while $\mathrm{N}$ values di- verge from those for the Earth heat content in some models, which may suggest that those models have biases in their represented energy budget. Particularly, the CESM1CAM5, CMCC-CM, GFDL-CM3, HADGEM2-CC, INMCM4, IPSL-CM5A-LR, IPSL-CM5A-MR, IPSL-CM5B-LR, NOR-ESM1-M and NOR-ESM1-ME models show N-EHC differences larger than $10 \%$ of their simulated changes in 
Table 2. Earth heat inventory and proportion of heat allocated in each climate subsystem from the 30 CMIP5 GCMs analysed here (MMM), and observations from Church et al. (2011) (Ch11) and von Schuckmann et al. (2020) (vS20). Heat storage in ZJ, heat proportion in $\%$.

\begin{tabular}{lrrr}
\hline Magnitude & MMM & Ch11 & vS20 \\
\hline $\mathrm{N}$ & $264 \pm 171$ & - & - \\
$\mathrm{EHC}$ & $256 \pm 177$ & 212 & $188 \pm 17$ \\
$\mathrm{OHC}$ & $247 \pm 172$ & 199 & $164 \pm 17$ \\
$\mathrm{GHC}$ & $5 \pm 9$ & 4 & $14 \pm 3$ \\
$\mathrm{AHC}$ & $2 \pm 2$ & 2 & $2.2 \pm 0.3$ \\
$\mathrm{CHC}$ & $2 \pm 3$ & 7 & $7 \pm 1$ \\
$\mathrm{CHC}$ (only sea ice) & $2 \pm 2$ & 2 & $2.5 \pm 0.2$ \\
\hline OHC / N & $93 \pm 24$ & - & - \\
$\mathrm{OHC} /$ EHC & $96 \pm 4$ & 94 & $88 \pm 12$ \\
OHC / EHC (only sea ice) & $96 \pm 4$ & 96 & $90 \pm 12$ \\
GHC / N & $2 \pm 3$ & - & - \\
GHC / EHC & $2 \pm 3$ & 2 & $7 \pm 2$ \\
GHC / EHC (only sea ice) & $2 \pm 3$ & 2 & $7 \pm 2$ \\
$\mathrm{AHC} / \mathrm{N}$ & $1.0 \pm 0.9$ & - & - \\
$\mathrm{AHC} /$ EHC & $1 \pm 1$ & 0.9 & $1.1 \pm 0.2$ \\
$\mathrm{AHC} /$ EHC (only sea ice) & $1 \pm 1$ & 0.9 & $1.1 \pm 0.2$ \\
CHC / N & $1 \pm 1$ & - & - \\
CHC / EHC & $1 \pm 1$ & 3 & $3.6 \pm 0.7$ \\
$\mathrm{CHC} /$ EHC (only sea ice) & $1 \pm 1$ & 1 & $1.2 \pm 0.2$ \\
\hline
\end{tabular}

OHC (Fig. 2a). Furthermore, the inter-model spread obtained for these three magnitudes is excessively large, given that all Historical simulations were forced using the same boundary conditions - i.e. the same external forcing. Further details about the large spread among the CMIP5 simulations as well as the discrepancies in $\mathrm{N}, \mathrm{EHC}$ and $\mathrm{OHC}$ can be found in the Discussion section.

A different situation is found for the magnitude of the simulated heat storage within the continental subsurface, with the CMIP5 ensemble mean yielding generally lower estimates of GHC than the observations (Fig. 2b). The multimodel mean achieves a GHC change of $5 \pm 9 \mathrm{ZJ}$ for 1972 $2005 \mathrm{CE}$, which is lower than the $14 \pm 3 \mathrm{ZJ}$ in von Schuckmann et al. (2020) but similar to the $\sim 4 \mathrm{ZJ}$ in Church et al. (2011) (Table 2). However, the difference between the GHC estimates in Church et al. (2011) and in von Schuckmann et al. (2020) is large (Fig. 2), probably caused by the different source of data used in both products. That is, results from Church et al. (2011) are based on surface air temperatures while results from von Schuckmann et al. (2020) are based on subsurface temperatures (see Huang, 2006; Cuesta-Valero et al., 2021, and the Data and methods section for more details). Therefore, the estimate of $14 \pm 3 \mathrm{ZJ}$ from von Schuckmann et al. (2020) constitutes a more robust reference for evaluating the simulated ground heat content by the CMIP5 ensemble, indicating that models underestimate observations of continental heat storage. Additionally, the representation of GHC in the CMIP5 GCMs is markedly limited by the simulated subsurface volume, which is determined by the depth of the land surface model (LSM) component (Stevens et al., 2007; MacDougall et al., 2008; Cuesta-Valero et al., 2016). Indeed, five of seven GCMs using LSM components deeper than $40 \mathrm{~m}$ yield GHC estimates are in agreement with the $95 \%$ confidence interval of observations from von Schuckmann et al. (2020), suggesting that the underestimated continental heat storage and the large spread in the CMIP5 ensemble are direct consequences of the different bottom boundary depths used by each model (see Cuesta-Valero et al., 2016, for a complete list of bottom boundary depths). The negative GHC estimates for both MRI simulations in Fig. $2 b$ are caused by an unrealistic and sharp decrease in the total water content in the subsurface along these Historical simulations (see Cuesta-Valero et al., 2016, for more details).

The CMIP5 ensemble mean constantly underestimates the cryosphere heat content in comparison with observations (Fig. 2b). The multimodel average estimates a $2 \pm 3 \mathrm{ZJ}$ change in the cryosphere heat content for the period 1972$2005 \mathrm{CE}$, which is much lower than the observed CHC in Church et al. (2011) (7 ZJ) and in von Schuckmann et al. (2020) ( $7 \pm 1 \mathrm{ZJ}$, Table 2). Figure 3 examines the three components contributing to the cryosphere heat content in this analysis for each CMIP5 model (i.e. sea ice, subsurface ice and glaciers), in order to understand the reason for the disagreement between simulated and observed CHC estimates. The simulated heat uptake to reduce sea ice volume is in agreement with observations, with a multimodel mean of $2 \pm 2 \mathrm{ZJ}$, while observations reach $\sim 2$ and $2.5 \pm 0.2 \mathrm{ZJ}$ in Church et al. (2011) and von Schuckmann et al. (2020), respectively (Fig. 3, Table 2). However, the spread in the CMIP5 results is still large, with the difference between the highest and the lowest estimates of heat storage due to sea ice melting being more than double the value of the ensemble mean $(5 \mathrm{ZJ})$. Heat uptake by subsurface ice is the second contributor to the cryosphere heat content in all models after sea ice melting. Nevertheless, neither Church et al. (2011) nor von Schuckmann et al. (2020) include observations of the change in terrestrial subsurface ice, and not all CMIP5 GCMs include a representation of the subsurface ice masses; thus we cannot assess the ability of the CMIP5 GCMs to reproduce this term of the cryosphere heat content. Furthermore, the approximation used in this study to estimate the simulated heat absorbed by glaciers yields a much smaller value from models than from observations $(\sim 2.8 \mathrm{ZJ}$ in Church et al., 2011 and $\sim 1.4 \mathrm{ZJ}$ in von Schuckmann et al., 2020), indicating that a comprehensive representation of terrestrial ice masses is necessary to reproduce observations.

The heat storage within the atmosphere yields the best results for the CMIP5 GCMs in comparison with observations (Fig. 2b). The CMIP5 ensemble mean achieves an atmosphere heat content of $2 \pm 2 \mathrm{ZJ}$, in agreement with observations from Church et al. (2011) (2ZJ) and von Schuckmann et al. (2020) (2.2 $\pm 0.3 \mathrm{ZJ})$. Additionally, one-third of 


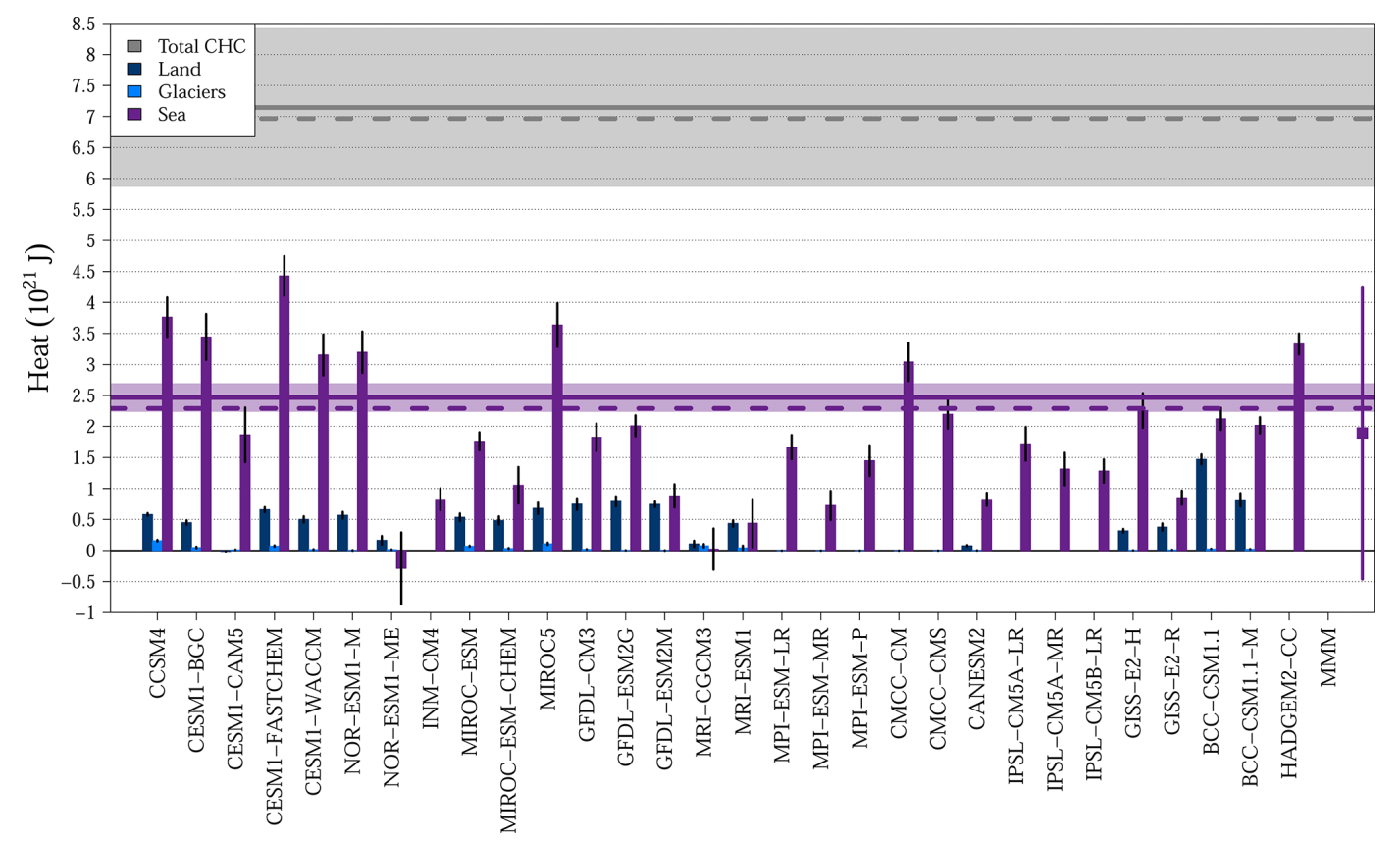

Figure 3. Simulated CHC for 1972-2005 CE. Dark blue bars indicate the heat uptake due to changes in subsurface ice mass, blue bars indicate the heat uptake due to changes in glacier mass, and purple bars indicate the heat uptake due to changes in sea ice volume (see Sect. 2 for details). Vertical black lines at the top of the bars indicate the $95 \%$ confidence interval for each model. The multimodel mean and $95 \%$ confidence interval for the heat uptake due to changes in sea ice volume are indicated in the right side of the panel (MMM). Observations from von Schuckmann et al. (2020) are shown as solid horizontal lines and shadows (means and $95 \%$ confidence intervals), and observations from Church et al. (2011) are displayed as dashed horizontal lines.

the models displays AHC estimates within the $95 \%$ confidence interval of the observed atmosphere heat content. Despite the similarity between the multimodel mean and observations, the inter-model spread is large, with the difference between the maximum and minimum AHC from CMIP5 models reaching $5 \mathrm{ZJ}$, more than double the value of the observational estimate.

\subsection{Heat partition within climate subsystems}

The simulated heat storage within each climate subsystem has been assessed in the previous section, displaying a large inter-model spread among CMIP5 GCMs. This wide range of results hampers the assessment of the simulated Earth heat inventory, particularly the evaluation of the represented ocean heat content and total heat in the climate system. Nevertheless, models may be distributing the total heat content among the four climate subsystems similarly. This section evaluates the partition of heat among climate subsystems within each CMIP5 GCM, testing whether models simulating higher values of $\mathrm{N}$ and $\mathrm{EHC}$ distribute this energy in the same proportion among climate subsystems as models simulating lower values of total heat content.

The simulated heat partitions by the 30 CMIP5 GCMs achieve a lower inter-model spread in comparison with the simulated EHI, particularly for the ocean component (Figs. 4 and 5, Table 2). Nevertheless, the ensemble mean presents a partition of heat in each climate subsystem similar to the results for the EHI. That is, the simulated proportion of energy in the ocean is larger than observations, the proportion of heat in the continental subsurface and in the cryosphere is lower than observations, and the proportion of heat in the atmosphere is in agreement with observations. Additionally, results vary depending on the metric used to characterize total heat content in the system, particularly for the ocean.

All 30 CMIP5 GCM simulations represent a proportion of heat stored in the ocean within the $95 \%$ confidence interval of the observations considering $\mathrm{EHC}$ as the metric for total energy in the climate system ( $\mathrm{OHC} / \mathrm{EHC}$, blue dots in Fig. 4a), achieving a multimodel mean just $2 \%$ higher than Church et al. (2011) and $8 \%$ higher than von Schuckmann et al. (2020) (Table 2). The spread of OHC / EHC estimates is small, with values ranging from $91 \pm 2 \%$ (MIROC5) to $100 \pm$ $1 \%$ (MRI-CGCM3). Nevertheless, the simulated proportion of heat in the ocean presents different results for some models when considering the integration of the radiative imbalance at the top of the atmosphere as the metric for total heat in the climate system (OHC / N, black dots in Fig. 4a). The model spread is much larger for $\mathrm{OHC} / \mathrm{N}$ estimates than for $\mathrm{OHC} / \mathrm{EHC}$ estimates, ranging from $56 \pm 2 \%$ (CMCC-CM) to $122 \pm 4 \%$ (NOR-ESM1-M). These different estimates are related to the differences between $\mathrm{N}$ and $\mathrm{EHC}$ values dis- 

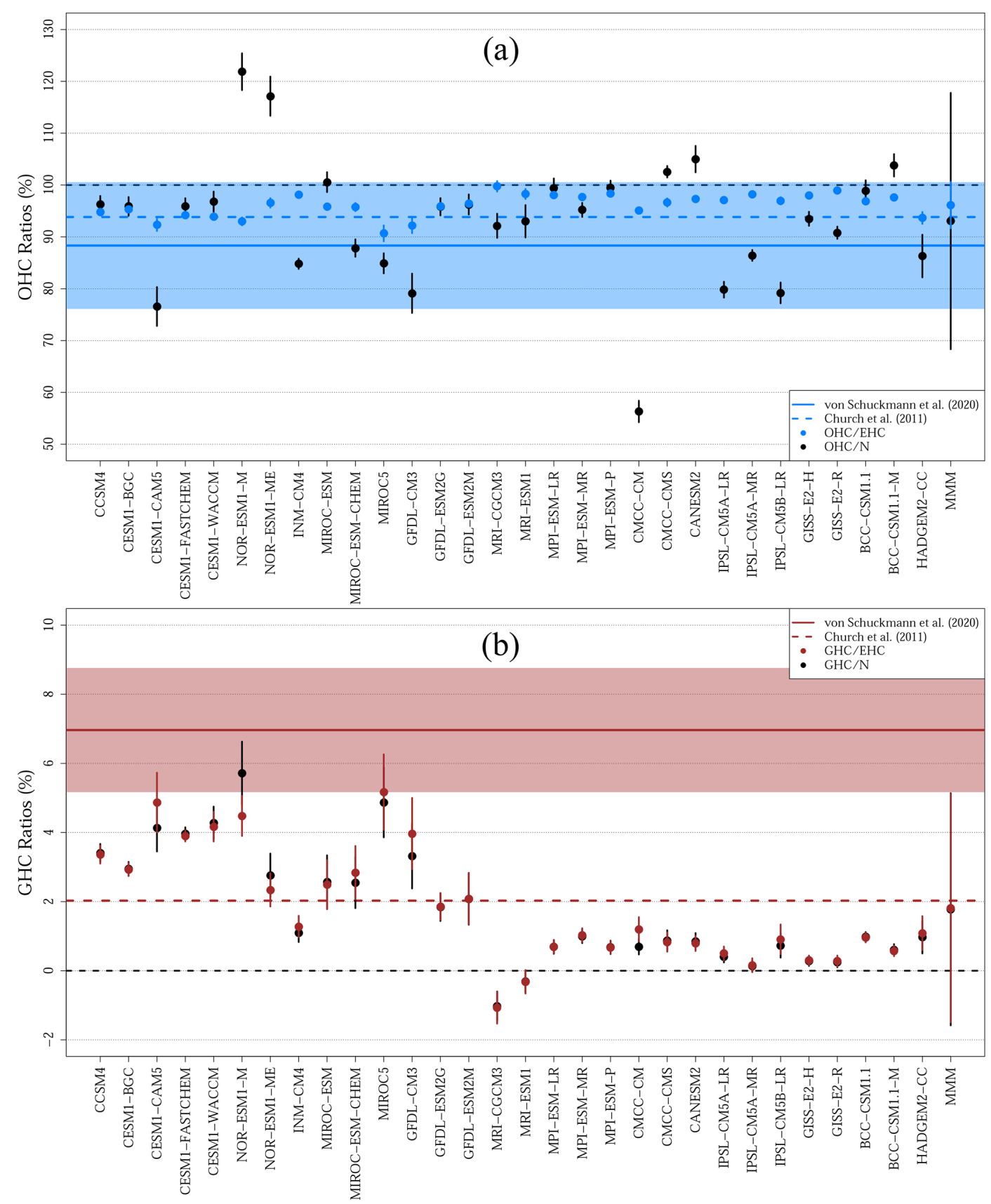

Figure 4. (a) Simulated proportion of heat within the ocean for the period 1972-2005 CE using EHC (blue dots) and N (black dots) as estimates of total heat content in the climate system. (b) Simulated proportion of heat within the continental subsurface for the period 19722005 CE using EHC (red dots) and N (black dots) as estimates of total heat content in the climate system. Observations from von Schuckmann et al. (2020) are shown as solid horizontal lines and shadows (means and $95 \%$ confidence intervals), and observations from Church et al. (2011) are displayed as dashed horizontal lines. Multimodel means and $95 \%$ confidence intervals are indicated in the right side of the panels (MMM). Black dashed lines indicate the $0 \%$ and $100 \%$ values.

played in Fig. 2a. That is, some CMIP5 models yield excessively different values of $\mathrm{N}$ and EHC, suggesting the presence of non-conservation terms in the simulated energy budget (see Sects. 3.1 and 4). Six models obtain $\mathrm{OHC} / \mathrm{N}$ estimates above $100 \%$, which indicates that the simulated $\mathrm{N}$ in those models is much lower than EHC estimates (the BCC-CSM1.1-M, CANESM2, CMCC-CMS, MIROC-ESM, NOR-ESM-M and NOR-ESM-ME models in Fig. 4a). The opposite behaviour occurs in other five models that simulate OHC / N values below $80 \%$ (the CESM1-CAM5, CMCC- 

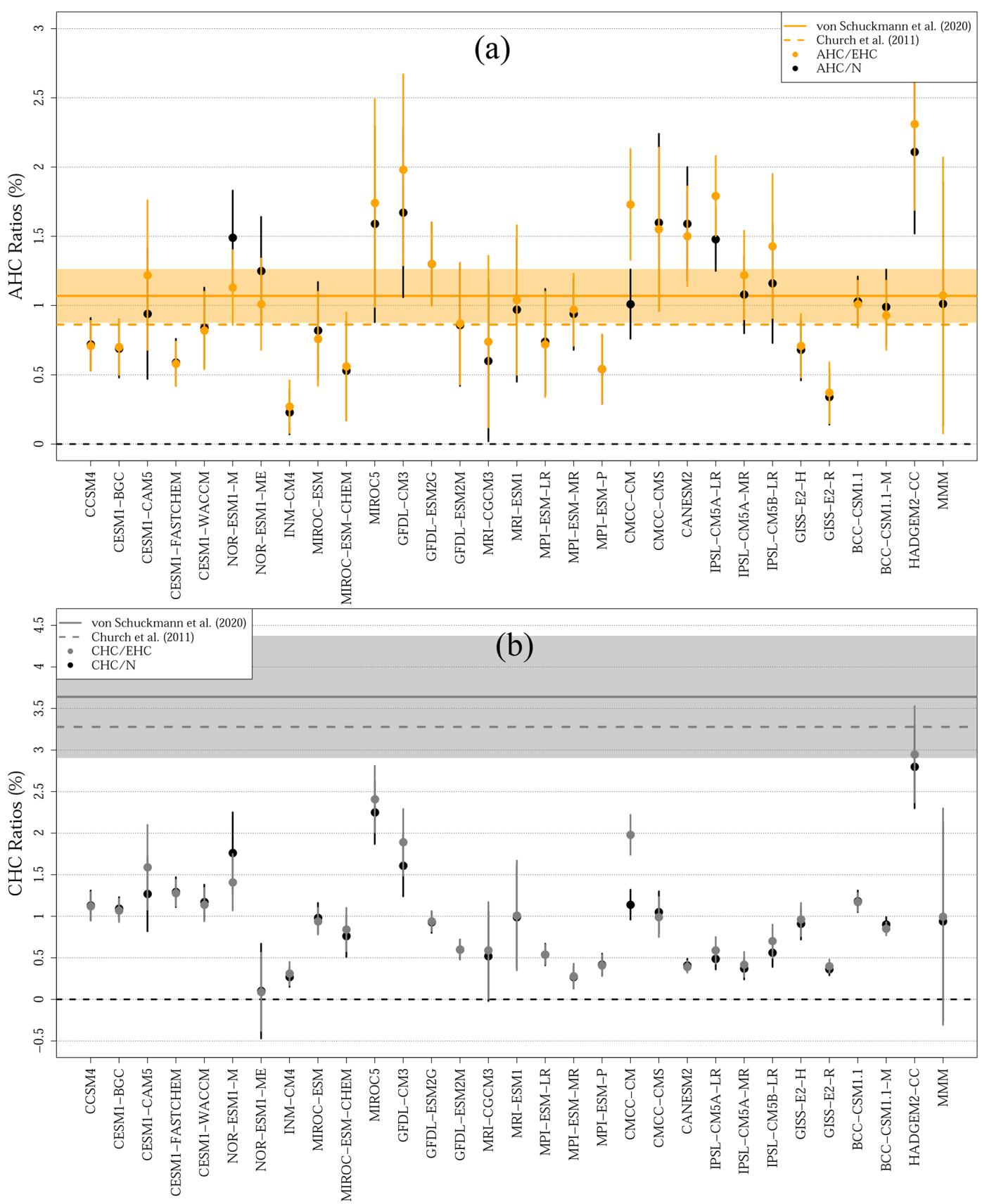

Figure 5. (a) Simulated proportion of heat within the atmosphere for the period 1972-2005 CE using EHC (orange dots) and N (black dots) as estimates of total heat content in the climate system. (b) Simulated proportion of heat within the continental subsurface for the period 19722005 CE using EHC (light blue dots) and N (black dots) as estimates of total heat content within the climate system. Observations from von Schuckmann et al. (2020) are shown as solid horizontal lines and shadows (means and $95 \%$ confidence intervals), and observations from Church et al. (2011) are displayed as dashed horizontal lines. Multimodel means and $95 \%$ confidence intervals are indicated in the right side of the panels (MMM). The black dashed line indicate the $0 \%$ value.

CM, GFDL-CM3, IPSL-CM5A-LR and IPSL-CM5B-LR models in Fig. 4a), which is probably an excessively small proportion of heat stored in the ocean in comparison with observations (Hansen et al., 2011; Palmer et al., 2011; Rhein et al., 2013; Palmer and McNeall, 2014; Trenberth et al., 2014; Hobbs et al., 2016; von Schuckmann et al., 2016, 2020).

Estimates of the proportion of heat in the ground from CMIP5 GCMs show smaller differences between GHC / N and GHC / EHC than the retrieved proportion of heat in the 
ocean (Fig. 4b). Both GHC / N and GHC / EHC estimates have a multimodel mean and $95 \%$ confidence interval of $2 \pm 3 \%$, which is in agreement with estimates derived from Church et al. (2011) $(\sim 2 \%)$, but excessively low in compari-

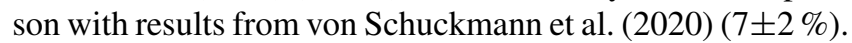
As in the case of the simulated ground heat content, the relatively large inter-model spread in the simulated proportion of heat stored in the continental subsurface is caused by the depth of the LSM component. Indeed, deeper models reach higher proportions of heat in the ground than shallower models using either EHC or $\mathrm{N}$ as the metric for total heat in the climate system. This marked dependence on the depth of the represented subsurface is apparent in a covariance analysis, with significant correlation coefficients between the depth of the LSM component and the GHC / N and GHC / EHC estimates (Fig. S3).

As in the case of the continental subsurface, CMIP5 GCMs consistently underestimate the observed proportion of heat absorbed by the cryosphere. Both metrics of total heat content in the system yield similar ratios (CHC / N and $\mathrm{CHC} / \mathrm{EHC}$ ), with only one model (the HADGEM2CC) reaching the $95 \%$ confidence interval from von Schuckmann et al. (2020) (Fig. 5). This disagreement between observations and CMIP5 simulations is expected given the large differences in the simulated and observed cryosphere heat content (Fig. 2b), while the partial agreement between the HADGEM2-CC estimates and the observations is likely the result of the low EHC and N values simulated by this model (Fig. 2a). Nevertheless, CMIP5 models and observations agree if considering only the heat allocated for sea ice melting (Table 2), with the multimodel average yielding an average of $1 \pm 1 \%$ in comparison with $1 \%$ from Church et al. (2011) and 1.2 $\pm 0.2 \%$ from von Schuckmann et al. (2020).

The CMIP5 GCMs also show similar estimates for the proportion of heat in the atmosphere using both $\mathrm{EHC}$ and $\mathrm{N}$ metrics. A large proportion of the models achieve AHC / N and AHC / EHC ratios within the $95 \%$ confidence interval from von Schuckmann et al. (2020) and contain the observational estimates from Church et al. (2011) within the limits of their individual confidence intervals (Fig. 5). The ensemble average yields a proportion of heat in the atmosphere of around $1 \pm 1 \%$, with observations reporting $0.9 \%$ (Church et al., 2011) and $1.1 \pm 0.2 \%$, which is a reassuring result for the CMIP5 models (von Schuckmann et al., 2020, Table 2).

\section{Discussion}

The 30 CMIP5 GCMs analysed here simulate markedly different total heat contents within the climate system, independently of the analysed metric (N, EHC and OHC values in Fig. 2a), which may be caused by the different response from each model to the common Historical forcing. That is, different models simulate distinct responses to the common external forcing, as seen in the broad range of simulated equilib-

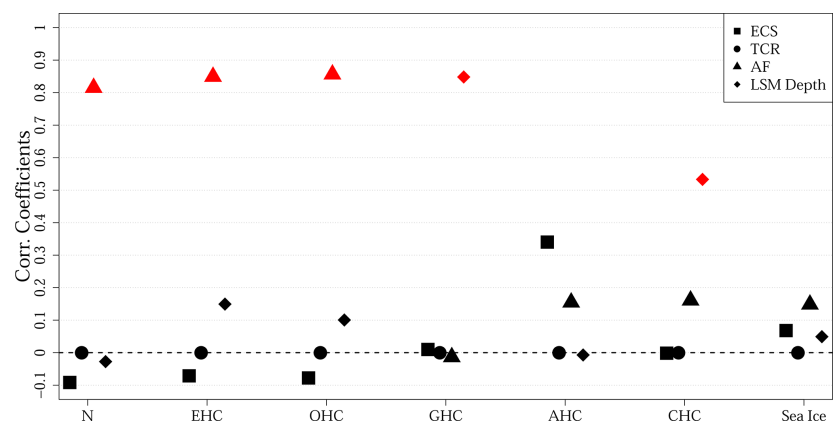

Figure 6. Correlation coefficients between the simulated equilibrium climate sensitivity (ECS, squares), transient climate response (TCR, circles), adjusted forcing (AF, triangles), depth of the LSM component (LSM depth, diamonds) and the components of the Earth heat inventory. Results obtained by analysing the 18 models presenting estimates of ECS, TCR and AF in Forster et al. (2013). Red symbols indicate statistically significant results at the $95 \%$ confidence level using a Student's $t$ test. The dashed black horizontal line indicates zero values.

rium climate sensitivities in the literature (e.g. Knutti et al., 2017). Indeed, Forster et al. (2013) assessed the response to the common forcing of a large ensemble of CMIP5 GCMs in terms of climate sensitivity, feedbacks and adjusted radiative forcing, showing that these models yielded a broad range of responses. To test the potential relationship between total heat storage and model response, we performed a covariance analysis between some of the metrics used by Forster et al. (2013) to characterize the response of CMIP5 models and the estimated Earth heat inventory here (Fig. 6). The 18 CMIP5 models in common with those analysed in Forster et al. (2013) do not show covariance between the heat storage within the different climate subsystems and equilibrium climate sensitivity nor with the transient climate response. However, the adjusted forcing during the last part of the Historical experiment (2001-2005 CE) presents significant correlation coefficients with $\mathrm{N}, \mathrm{EHC}$ and $\mathrm{OHC}$ (red triangles in Fig. 6). This is a reasonable result, as different adjusted forcings result from a spread of radiative imbalances at the top of the atmosphere and climate sensitivities, from which different $\mathrm{N}$ values arise - and therefore distinct heat storage within the ocean (Palmer and McNeall, 2014). The relationship between adjusted forcing and heat storage, nevertheless, should be considered just as a potential line of research, since the estimates of radiative forcing from transient climate simulations depend on the method employed in the analysis (Forster et al., 2016), meaning that further work is needed to evaluate the robustness of this relationship.

The simulated proportion of heat in the ocean for some models shows markedly different results depending on the metric used for total heat content in the climate system (Fig. 4a). The different heat partition is caused by the discrepancies between estimates of $\mathrm{N}$ and EHC within each GCM simulation (Fig. 2a), which are probably related to 
non-conservation terms in the simulated energy budget by each GCM as discussed in Hobbs et al. (2016). That is, small numerical inconsistencies, insufficient spin-up time, or the amount of water leaving the LSM component at the bottom of the soil column, among other factors, may prevent the conservation of energy in GCM simulations (Sen Gupta et al., 2013; Hobbs et al., 2016; Séférian et al., 2016; Trenberth et al., 2016). We applied a simple drift-removal technique to each variable considered in this study in order to minimize the effect of possible non-conservation terms in our results (see Sect. 2). This method has shown good results in previous analyses including several CMIP5 experiments, although no perfect solution is available yet (Hobbs et al., 2016).

The low ground heat content achieved by the shallow LSM components (Fig. 2b) alters the distribution of heat within models, mainly causing a higher proportion of heat stored in the ocean if considering EHC as the metric for total heat content. This can be seen in a covariance analysis between OHC / EHC estimates and the depth of the LSM components in the CMIP5 ensemble (Fig. S3). The shallow depth of the LSM components included in the CMIP5 GCMs limits the represented amount of continental heat storage within each simulation (Stevens et al., 2007; MacDougall et al., 2008; Cuesta-Valero et al., 2016; Hermoso de Mendoza et al., 2020), altering the GHC estimates and the obtained GHC / EHC and GHC / N ratios from the 30 CMIP5 GCMs analysed here (Figs. 2b, 4b and S3). Simulated OHC / N values, nevertheless, do not present such covariance with the depth of the LSM component, nor the simulated proportion of heat in the atmosphere and the cryosphere (Figs. S3 and S4). Surprisingly, the simulated CHC indicates significant covariance with the depth of the employed LSM component (red diamond in Fig. 6), although this should be the result of the different subsurface volume within CMIP5 models. That is, deeper models tend to simulate more subsurface ice and GHC than shallower models, and therefore more heat can be used to thaw the larger mass of subsurface ice. This result suggests another limit to the representation of the EHI within GCM simulations, as the lack of a sufficient continental subsurface volume alters the simulated heat uptake by the subsurface ice masses. Nevertheless, further work is required to clarify this point.

The simulated cryosphere heat content and heat proportion are in better agreement with observations when ignoring the heat absorbed by terrestrial ice masses from the assessment, that is, considering sea ice as the only cryosphere component (see results labelled as "only sea ice" in Table 2). The same can be said about the simulated proportion of heat in the ocean, which shows a reduction of $2 \%$ in the difference with observations if considering only sea ice as cryosphere (Table 2). This is caused by the lack of a representation of land ice in CMIP5 simulations, as only the simulated heat uptake by sea ice can be directly compared with observations, and the method used here to approximate the melting of land ice in the models is not accurate enough. Our approach consid- ers snow changes in grid cells indicated as land ice by the models, but results show that this method markedly underestimates heat uptake in comparison with observations (Fig. 3). Furthermore, the observed proportion of heat in the ocean yields different results if considering the whole cryosphere for estimating EHC or if considering only the change in sea ice volume (Table 2). Therefore, heat uptake by terrestrial ice sheets and glaciers is important to improve the simulated EHI and the partition of heat within the four climate subsystems. CMIP5 GCMs currently include modules representing ice sheets, but such model components were not activated for generating the CMIP5 simulations analysed here, probably due to issues with computational resources and technical challenges of coupling the ice sheet grids with the rest of the subsystems (Flato et al., 2013). New experiments are planned to assess the ability of the latest generation of GCMs to reproduce the ice sheets of Greenland and Antarctica within the sixth phase of the Coupled Model Intercomparison Project (CMIP6), including coupled atmosphere-oceanice-sheet simulations (Nowicki et al., 2016). Although these experiments are focused on understanding the contribution of ice sheets to sea-level rise, these simulations could be also useful to test whether including land ice masses enhances the representation of the Earth heat inventory within GCMs, particularly the coupled experiments.

\section{Conclusions}

The ensemble of CMIP5 GCMs analysed here overestimates the amount of heat stored in the ocean and underestimates the heat uptake by the cryosphere and the continental subsurface, while representing changes in atmosphere heat storage similar to observations. Models present a large inter-model spread of ocean heat content and total heat content in the system, probably related to the wide range of simulated responses to external forcing in these GCMs. The lack of an adequate representation of terrestrial ice masses and continental subsurface volume within CMIP5 models limits the amount of heat allocated within the cryosphere and the continental subsurface. The issue of heat conservation within complex numerical simulations also affects the Earth heat inventory represented in the CMIP5 ensemble. Nevertheless, there is good agreement between simulated and observed atmosphere heat storage and heat uptake by changes in sea ice volume.

There are two main issues hindering the assessment of the EHI in CMIP5 models in comparison with observations: the non-conservation of energy in models and the markedly different amounts of simulated total heat content in the Earth system. Ocean heat storage is markedly high within the CMIP5 ensemble, presenting high inter-model variability. This causes a much higher Earth heat content in the models in comparison with observations. The different response of each model to the external forcing may be the cause for this large variability and high values of $\mathrm{OHC}$ and $\mathrm{EHC}$, suggest- 
ing that simulations from the CMIP6 models may present an even larger spread in results, since Meehl et al. (2020) found a larger inter-model variability for estimates of equilibrium climate sensitivity (ECS) in this new generation of models. Otherwise, the spread in effective radiative forcing (ERF) is similar in CMIP5 and CMIP6 (Smith et al., 2020), and the simulated radiative imbalance seems to present smaller inter-model variability in the CMIP6 ensemble than in the CMIP5 ensemble (Wild, 2020). Therefore, a future assessment of the simulated EHI within the CMIP6 ensemble is required to determine the performance of the new generation of models. Regarding the non-conservation of energy within the models, Irving et al. (2020) have found that drifts in $\mathrm{N}$ and $\mathrm{OHC}$ are still markedly large in CMIP6 models, although the energy leakage within these models has improved in comparison with CMIP5 simulations. Nevertheless, such a result indicates that an assessment of the EHI represented by CMIP6 models will encounter similar burdens and limitations to those in our analysis, including the need to apply a drift correction technique before evaluating the simulations.

The assessment of transient climate simulations in comparison with observations presented here indicates that deeper continental subsurfaces and some representation of terrestrial ice masses within GCMs are required to improve the simulated Earth heat inventory, as well as the associated phenomena relevant to society such as sea level rise or permafrost evolution. These issues will probably be present within the CMIP6 simulations, together with nonconservation of energy and drifts, but the comparison with observational references may help to mitigate these limitations in future generations of GCMs. For example, an extended sampling of the deepest part of the ocean will improve the observational estimate of $\mathrm{OHC}$ and will provide a reference to evaluate deep heat uptake in GCMs, probably reducing the drift in these models (Irving et al., 2020; von Schuckmann et al., 2020). Local and regional measurements of the state of glaciers and ice sheets may help to parameterize the evolution of ice masses in individual grid cells. That is, a simplified parameterization of land ice masses based on tiling (Essery et al., 2003; Best et al., 2004) could be implemented. This strategy has been successful in representing vegetation functional types at sub-grid scales (Melton and Arora, 2014), and it has been proposed to improve the representation of permafrost in land surface model components (Beer, 2016). Additionally, expanding the global network of subsurface temperature profiles will improve the estimates of continental heat storage, mitigating the scarcity of measurements after $2000 \mathrm{CE}$ and in the Southern Hemisphere (Cuesta-Valero et al., 2021).

Furthermore, the collaboration between the observational and modelling communities should be maintained and expanded to further advance our knowledge of key climate processes. Assessments of transient climate simulations based on observational estimates of important climate variables, like the analysis performed here, have been showing paths for improvement in climate modelling for a long time now. The analysis of CMIP6 simulations will allow for testing of the improvement of advanced climate models in reproducing the evolution of climate change, but in order to maintain the progress in modelling and to enhance the understanding of the processes conforming the Grand Challenges of the World Climate Research Program (WCRP), the global network of observations must be maintained and expanded.

Data availability. CMIP5 simulations can be accessed at the dedicated website of the Earth System Grid Federation (https: //esgf-node.llnl.gov/projects/cmip5/, last access: 3 May 2021) (WCRP, 2021). Data from von Schuckmann et al. (2020) are available at https://doi.org/10.26050/WDCC/GCOS_EHI_EXP_v2 (last access: 3 May 2021), and data from Church et al. (2011) can be retrieved from the publication itself.

Supplement. The supplement related to this article is available online at: https://doi.org/10.5194/esd-12-581-2021-supplement.

Author contributions. FJCV designed the study, analysed the CMIP5 simulations, and produced all results and figures. All authors contributed to the interpretation and discussion of results. FJCV wrote the paper with continuous feedback from all authors.

Competing interests. The authors declare that they have no conflict of interest.

Acknowledgements. We acknowledge the World Climate Research Programme's Working Group on Coupled Modelling, which is responsible for CMIP, and we thank the climate modelling groups responsible for the model simulations used herein (listed in Table 1 of this paper) for producing and making available their model output. For CMIP the US Department of Energy's Program for Climate Model Diagnosis and Intercomparison provides coordinating support and led development of software infrastructure in partnership with the Global Organization for Earth System Science Portals. This analysis contributes to the PALEOLINK project (http://www.pastglobalchanges.org/science/wg/2k-network/ projects/paleolink/intro, last access: 4 May 2021), part of the PAGES $2 \mathrm{k}$ Network. Part of the presented analysis was performed in the computational facilities provided by the Atlantic Computational Excellence Network (ACENET-Compute Canada). We thank two anonymous reviewers for their constructive feedback. We are grateful to Fiammetta Straneo and Susheel Adusumilli for their help with obtaining and Page 2 of 3 interpreting the sea ice volume data. This work was supported by grants from the Natural Sciences and Engineering Research Council of Canada Discovery Grant (NSERC DG 140576948), the Canada Research Chairs Program (CRC 230687), and the Canada Foundation for Innovation (CFI) to Hugo Beltrami. Almudena García-García and Francisco José Cuesta-Valero are funded by Hugo Beltrami's Canada Research Chair program, the School of Graduate Students at 
Memorial University of Newfoundland and the Research Office at St. Francis Xavier University.

Financial support. This research has been supported by the Canada Research Chairs (grant no. CRC 230687) and the Natural Sciences and Engineering Research Council of Canada (grant no. NSERC DG 140576948).

Review statement. This paper was edited by Govindasamy Bala and reviewed by two anonymous referees.

\section{References}

Adachi, Y., Yukimoto, S., Deushi, M., Obata, A., Nakano, H., Tanaka, T. Y., Hosaka, M., Sakami, T., Yoshimura, H., Hirabara, M., Shindo, E., Tsujino, H., Mizuta, R., Yabu, S., Koshiro, T., Ose, T., and Kitoh, A.: Basic performance of a new earth system model of the Meteorological Research Institute (MRI-ESM1), Pap. Meteorol. Geophys., 64, 1-19, https://doi.org/10.2467/mripapers.64.1, 2013.

Allan, R. P., Liu, C., Loeb, N. G., Palmer, M. D., Roberts, M., Smith, D., and Vidale, P.-L.: Changes in global net radiative imbalance 1985-2012, Geophys. Res. Lett., 41, 5588-5597, https://doi.org/10.1002/2014GL060962, 2014.

Arora, V. K., Scinocca, J. F., Boer, G. J., Christian, J. R., Denman, K. L., Flato, G. M., Kharin, V. V., Lee, W. G., and Merryfield, W. J.: Carbon emission limits required to satisfy future representative concentration pathways of greenhouse gases, Geophys. Res. Lett., 38, L05805, https://doi.org/10.1029/2010GL046270, 2011.

Bamber, J. L., Westaway, R. M., Marzeion, B., and Wouters, B.: The land ice contribution to sea level during the satellite era, Environ. Res. Lett., 13, 063008, https://doi.org/10.1088/17489326/aac2f0, 2018.

Beer, C.: Permafrost Sub-grid Heterogeneity of Soil Properties Key for 3D Soil Processes and Future Climate Projections, Front. Earth Sci., 4, 81, https://doi.org/10.3389/feart.2016.00081, 2016.

Best, M. J., Beljaars, A., Polcher, J., and Viterbo, P.: A Proposed Structure for Coupling Tiled Surfaces with the Planetary Boundary Layer, J. Hydrometeorol., 5, 1271-1278, https://doi.org/10.1175/JHM-382.1, 2004.

Bhowmick, S. A., Agarwal, N., Ali, M. M., Kishtawal, C. M., and Sharma, R.: Role of ocean heat content in boosting post-monsoon tropical storms over Bay of Bengal during La-Niña events, Clim. Dynam., 52, 7225-7234, https://doi.org/10.1007/s00382-016-3428-5, 2016.

Biskaborn, B. K., Smith, S. L., Noetzli, J., Matthes, H., Vieira, G., Streletskiy, D. A., Schoeneich, P., Romanovsky, V. E., Lewkowicz, A. G., Abramov, A., Allard, M., Boike, J., Cable, W. L., Christiansen, H. H., Delaloye, R., Diekmann, B., Drozdov, D., Etzelmüller, B., Grosse, G., Guglielmin, M., Ingeman-Nielsen, T., Isaksen, K., Ishikawa, M., Johansson, M., Johannsson, H., Joo, A., Kaverin, D., Kholodov, A., Konstantinov, P., Kröger, T., Lambiel, C., Lanckman, J.-P., Luo, D., Malkova, G., Meiklejohn, I., Moskalenko, N., Oliva, M., Phillips, M., Ramos, M., Sannel, A. B. K., Sergeev, D., Seybold, C., Skryabin, P., Vasiliev, A.,
Wu, Q., Yoshikawa, K., Zheleznyak, M., and Lantuit, H.: Permafrost is warming at a global scale, Nat. Commun., 10, 264, https://doi.org/10.1038/s41467-018-08240-4, 2019.

Campbell, B. M., Vermeulen, S. J., Aggarwal, P. K., CornerDolloff, C., Girvetz, E., Loboguerrero, A. M., RamirezVillegas, J., Rosenstock, T., Sebastian, L., Thornton, P. K., and Wollenberg, E.: Reducing risks to food security from climate change, Global Food Secur., 11, 34-43, https://doi.org/10.1016/j.gfs.2016.06.002, 2016.

Church, J. A., White, N. J., Konikow, L. F., Domingues, C. M., Cogley, J. G., Rignot, E., Gregory, J. M., van den Broeke, M. R., Monaghan, A. J., and Velicogna, I.: Revisiting the Earth's sealevel and energy budgets from 1961 to 2008 , Geophys. Res. Lett., 38, L18601, https://doi.org/10.1029/2011GL048794, 2011.

Collins, M., Sutherland, M., Bouwer, L., Cheong, S.-M., Frölicher, T., Jacot Des Combes, H., Koll Roxy, M., Losada, I., McInnes, K., Ratter, B., Rivera-Arriaga, E., Susanto, R., Swingedouw, D., and Tibig, L.: Extremes, Abrupt Changes and Managing Risk, in: IPCC Special Report on the Ocean and Cryosphere in a Changing Climate, edited by: Pörtner, H.-O., Roberts, D., MassonDelmotte, V., Zhai, P., Tignor, M., Poloczanska, E., Mintenbeck, K., Alegría, A., Nicolai, M., Okem, A., Petzold, J., Rama, B., and Weyer, N., in press, available at: https://www.ipcc.ch/site/assets/ uploads/sites/3/2019/11/10_SROCC_Ch06_FINAL.pdf (last access: 3 May 2021), 2019.

Collins, W. J., Bellouin, N., Doutriaux-Boucher, M., Gedney, N., Halloran, P., Hinton, T., Hughes, J., Jones, C. D., Joshi, M., Liddicoat, S., Martin, G., O’Connor, F., Rae, J., Senior, C., Sitch, S., Totterdell, I., Wiltshire, A., and Woodward, S.: Development and evaluation of an Earth-System model - HadGEM2, Geosci. Model Dev., 4, 1051-1075, https://doi.org/10.5194/gmd-4-10512011, 2011.

Cuesta-Valero, F. J., García-García, A., Beltrami, H., and Smerdon, J. E.: First assessment of continental energy storage in CMIP5 simulations, Geophys. Res. Lett., 43, 5326-5335, https://doi.org/10.1002/2016GL068496, 2016.

Cuesta-Valero, F. J., García-García, A., Beltrami, H., GonzálezRouco, J. F., and García-Bustamante, E.: Long-term global ground heat flux and continental heat storage from geothermal data, Clim. Past, 17, 451-468, https://doi.org/10.5194/cp-17451-2021, 2021.

Donner, L. J., Wyman, B. L., Hemler, R. S., Horowitz, L. W., Ming, Y., Zhao, M., Golaz, J.-C., Ginoux, P., Lin, S. J., Schwarzkopf, M. D., Austin, J., Alaka, G., Cooke, W. F., Delworth, T. L., Freidenreich, S. M., Gordon, C. T., Griffies, S. M., Held, I. M., Hurlin, W. J., Klein, S. A., Knutson, T. R., Langenhorst, A. R., Lee, H.-C., Lin, Y., Magi, B. I., Malyshev, S. L., Milly, P. C. D., Naik, V., Nath, M. J., Pincus, R., Ploshay, J. J., Ramaswamy, V., Seman, C. J., Shevliakova, E., Sirutis, J. J., Stern, W. F., Stouffer, R. J., Wilson, R. J., Winton, M., Wittenberg, A. T., and Zeng, F.: The Dynamical Core, Physical Parameterizations, and Basic Simulation Characteristics of the Atmospheric Component AM3 of the GFDL Global Coupled Model CM3, J. Climate, 24, 34843519, https://doi.org/10.1175/2011JCLI3955.1, 2011.

Dufresne, J.-L., Foujols, M.-A., Denvil, S., Caubel, A., Marti, O., Aumont, O., Balkanski, Y., Bekki, S., Bellenger, H., Benshila, R., Bony, S., Bopp, L., Braconnot, P., Brockmann, P., Cadule, P., Cheruy, F., Codron, F., Cozic, A., Cugnet, D., de Noblet, N., Duvel, J.-P., Ethé, C., Fairhead, L., Fichefet, T., Flavoni, 
S., Friedlingstein, P., Grandpeix, J.-Y., Guez, L., Guilyardi, E., Hauglustaine, D., Hourdin, F., Idelkadi, A., Ghattas, J., Joussaume, S., Kageyama, M., Krinner, G., Labetoulle, S., Lahellec, A., Lefebvre, M.-P., Lefevre, F., Levy, C., Li, Z., Lloyd, J., Lott, F., Madec, G., Mancip, M., Marchand, M., Masson, S., Meurdesoif, Y., Mignot, J., Musat, I., Parouty, S., Polcher, J., Rio, C., Schulz, M., Swingedouw, D., Szopa, S., Talandier, C., Terray, P., Viovy, N., and Vuichard, N.: Climate change projections using the IPSL-CM5 Earth System Model: from CMIP3 to CMIP5, Clim. Dynam., 40, 2123-2165, https://doi.org/10.1007/s00382012-1636-1, 2013.

Dunne, J. P., John, J. G., Adcroft, A. J., Griffies, S. M., Hallberg, R. W., Shevliakova, E., Stouffer, R. J., Cooke, W., Dunne, K. A., Harrison, M. J., Krasting, J. P., Malyshev, S. L., Milly, P. C. D., Phillipps, P. J., Sentman, L. T., Samuels, B. L., Spelman, M. J., Winton, M., Wittenberg, A. T., and Zadeh, N.: GFDL's ESM2 Global Coupled Climate-Carbon Earth System Models, Part I: Physical Formulation and Baseline Simulation Characteristics, J. Climate, 25, 6646-6665, https://doi.org/10.1175/JCLI-D-11$00560.1,2012$.

Dutton, A., Carlson, A. E., Long, A. J., Milne, G. A., Clark, P. U., DeConto, R., Horton, B. P., Rahmstorf, S., and Raymo, M. E.: Sea-level rise due to polar ice-sheet mass loss during past warm periods, Science, 349, aaa4019, https://doi.org/10.1126/science.aaa4019, 2015.

Dutton, J. A.: The Ceaseless Wind: An Introduction to the Theory of Atmospheric Motion, Dover Publications, Mineola, New York, USA, 2002.

Essery, R. L. H., Best, M. J., Betts, R. A., Cox, P. M., and Taylor, C. M.: Explicit Representation of Subgrid Heterogeneity in a GCM Land Surface Scheme, J. Hydrometeorol., 4, 530-543, https://doi.org/10.1175/15257541(2003)004<0530:EROSHI>2.0.CO;2, 2003.

Ferrari, R., Jansen, M. F., Adkins, J. F., Burke, A., Stewart, A. L., and Thompson, A. F.: Antarctic sea ice control on ocean circulation in present and glacial climates, P. Natl. Acad. Sci. USA, 111, 8753-8758, https://doi.org/10.1073/pnas.1323922111, 2014.

Flato, G., Marotzke, J., Abiodun, B., Braconnot, P., Chou, S., Collins, W., Cox, P., Driouech, F., Emori, S., Eyring, V., Forest, C., Gleckler, P., Guilyardi, E., Jakob, C., Kattsov, V., Reason, C., and Rummukainen, M.: Evaluation of Climate Models, in: Climate Change 2013: The Physical Science Basis, in: Contribution of Working Group I to the Fifth Assessment Report of the Intergovernmental Panel on Climate Change, edited by: Stocker, T., Qin, D., Plattner, G.-K., Tignor, M., Allen, S., Boschung, J., Nauels, A., Xia, Y., Bex, V., and Midgley, P., Cambridge University Press, Cambridge, UK and New York, USA, 741-866, https://doi.org/10.1017/CBO9781107415324.020, 2013.

Forster, P. M., Andrews, T., Good, P., Gregory, J. M., Jackson, L. S., and Zelinka, M.: Evaluating adjusted forcing and model spread for historical and future scenarios in the CMIP5 generation of climate models, J. Geophys. Res.-Atmos., 118, 11391150, https://doi.org/10.1002/jgrd.50174, 2013.

Forster, P. M., Richardson, T., Maycock, A. C., Smith, C. J., Samset, B. H., Myhre, G., Andrews, T., Pincus, R., and Schulz, M.: Recommendations for diagnosing effective radiative forcing from climate models for CMIP6, J. Geophys. Res.-Atmos., 121, 12460-12475, https://doi.org/10.1002/2016JD025320, 2016.
Gent, P. R., Danabasoglu, G., Donner, L. J., Holland, M. M., Hunke, E. C., Jayne, S. R., Lawrence, D. M., Neale, R. B., Rasch, P. J., Vertenstein, M., Worley, P. H., Yang, Z.-L., and Zhang, M.: The Community Climate System Model Version 4, J. Climate, 24, 4973-4991, https://doi.org/10.1175/2011JCLI4083.1, 2011.

Giorgetta, M. A., Jungclaus, J., Reick, C. H., Legutke, S., Bader, J., Böttinger, M., Brovkin, V., Crueger, T., Esch, M., Fieg, K., Glushak, K., Gayler, V., Haak, H., Hollweg, H.-D., Ilyina, T., Kinne, S., Kornblueh, L., Matei, D., Mauritsen, T., Mikolajewicz, U., Mueller, W., Notz, D., Pithan, F., Raddatz, T., Rast, S., Redler, R., Roeckner, E., Schmidt, H., Schnur, R., Segschneider, J., Six, K. D., Stockhause, M., Timmreck, C., Wegner, J., Widmann, H., Wieners, K.-H., Claussen, M., Marotzke, J., and Stevens, B.: Climate and carbon cycle changes from 1850 to 2100 in MPI-ESM simulations for the Coupled Model Intercomparison Project phase 5, J. Adv. Model. Earth Syst., 5, 572-597, https://doi.org/10.1002/jame.20038, 2013.

Gleckler, P. J., Durack, P. J., Stouffer, R. J., Johnson, G. C., and Forest, C. E.: Industrial-era global ocean heat uptake doubles in recent decades, Nat. Clim. Change, 6, 394-398, https://doi.org/10.1038/nclimate2915, 2016.

Griffies, S. M.: Fundamentals of Ocean Climate Models, Princeton University Press, Princeton, New Jersey, USA, 2004.

Hanna, E., Navarro, F. J., Pattyn, F., Domingues, C. M., Fettweis, X., Ivins, E. R., Nicholls, R. J., Ritz, C., Smith, B., Tulaczyk, S., Whitehouse, P. L., and Zwally, H. J.: Icesheet mass balance and climate change, Nature, 498, 51-59, https://doi.org/10.1038/nature12238, 2013.

Hansen, J., Sato, M., Kharecha, P., and von Schuckmann, K.: Earth's energy imbalance and implications, Atmos. Chem. Phys., 11, 13421-13449, https://doi.org/10.5194/acp-11-13421-2011, 2011.

Hegerl, G. C., Black, E., Allan, R. P., Ingram, W. J., Polson, D., Trenberth, K. E., Chadwick, R. S., Arkin, P. A., Sarojini, B. B., Becker, A., Dai, A., Durack, P. J., Easterling, D., Fowler, H. J., Kendon, E. J., Huffman, G. J., Liu, C., Marsh, R., New, M., Osborn, T. J., Skliris, N., Stott, P. A., Vidale, P.-L., Wijffels, S. E., Wilcox, L. J., Willett, K. M., and Zhang, X.: Challenges in Quantifying Changes in the Global Water Cycle, B. Am. Meteorol. Soc., 96, 1097-1115, https://doi.org/10.1175/BAMS-D13-00212.1, 2015.

Hermoso de Mendoza, I., Beltrami, H., MacDougall, A. H., and Mareschal, J.-C.: Lower boundary conditions in land surface models - effects on the permafrost and the carbon pools: a case study with CLM4.5, Geosci. Model Dev., 13, 1663-1683, https://doi.org/10.5194/gmd-13-1663-2020, 2020.

Hicks Pries, C. E., Castanha, C., Porras, R. C., and Torn, M. S.: The whole-soil carbon flux in response to warming, Science, 355 , 1420-1423, https://doi.org/10.1126/science.aal1319, 2017.

Hobbs, W., Palmer, M. D., and Monselesan, D.: An Energy Conservation Analysis of Ocean Drift in the CMIP5 Global Coupled Models, J. Climate, 29, 1639-1653, https://doi.org/10.1175/JCLI-D-15-0477.1, 2016.

Hock, R., Rasul, G., Adler, C., Cáceres, B., Gruber, S., Hirabayashi, Y., Jackson, M., Kääb, A., Kang, S., Kutuzov, S., Milner, A., Molau, U., Morin, S., Orlove, B., and Steltzer, H.: High Mountain Areas, in: IPCC Special Report on the Ocean and Cryosphere in a Changing Climate, edited by: Pörtner, H.O., Roberts, D., Masson-Delmotte, V., Zhai, P., Tignor, M., 
Poloczanska, E., Mintenbeck, K., Alegría, A., Nicolai, M., Okem, A., Petzold, J., Rama, B., and Weyer, N., in press, available at: https://www.ipcc.ch/site/assets/uploads/sites/3/2019/11/ 06_SROCC_Ch02_FINAL.pdf (last access: 3 May 2021), 2019.

$\mathrm{Hu}$, A., Meehl, G. A., Han, W., Yin, J., Wu, B., and Kimoto, M.: Influence of Continental Ice Retreat on Future Global Climate, J. Climate, 26, 3087-3111, https://doi.org/10.1175/JCLI-D-1200102.1, 2013.

Huang, S.: 1851-2004 annual heat budget of the continental landmasses, Geophys. Res. Lett., 33, L04707, https://doi.org/10.1029/2005GL025300, 2006.

Hurrell, J. W., Holland, M. M., Gent, P. R., Ghan, S., Kay, J. E., Kushner, P. J., Lamarque, J.-F., Large, W. G., Lawrence, D., Lindsay, K., Lipscomb, W. H., Long, M. C., Mahowald, N., Marsh, D. R., Neale, R. B., Rasch, P., Vavrus, S., Vertenstein, M., Bader, D., Collins, W. D., Hack, J. J., Kiehl, J., and Marshall, S.: The Community Earth System Model: A Framework for Collaborative Research, B. Am. Meteorol. Soc., 94, 13391360, https://doi.org/10.1175/BAMS-D-12-00121.1, 2013.

Hurtt, G., Chini, L., Frolking, S., Betts, R., Feddema, J., Fischer, G., Fisk, J., Hibbard, K., Houghton, R., Janetos, A., Jones, C., Kindermann, G., Kinoshita, T., Klein Goldewijk, K., Riahi, K., Shevliakova, E., Smith, S., Stehfest, E., Thomson, A., Thornton, P., van Vuuren, D., and Wang, Y.: Harmonization of land-use scenarios for the period 1500-2100: 600 years of global gridded annual land-use transitions, wood harvest, and resulting secondary lands, Climatic Change, 109, 117-161, https://doi.org/10.1007/s10584-011-0153-2, 2011.

Irving, D., Hobbs, W., Church, J., and Zika, J.: A Mass and Energy Conservation Analysis of Drift in the CMIP6 Ensemble, J. Climate, 34, 3157-3170, https://doi.org/10.1175/JCLI-D-200281.1, 2020.

Iversen, T., Bentsen, M., Bethke, I., Debernard, J. B., Kirkevåg, A., Seland, Ø., Drange, H., Kristjansson, J. E., Medhaug, I., Sand, M., and Seierstad, I. A.: The Norwegian Earth System Model, NorESM1-M - Part 2: Climate response and scenario projections, Geosci. Model Dev., 6, 389-415, https://doi.org/10.5194/gmd-6-389-2013, 2013.

Jacob, T., Wahr, J., Pfeffer, W. T., and Swenson, S.: Recent contributions of glaciers and ice caps to sea level rise, Nature, 482, 514-518, https://doi.org/10.1038/nature10847, 2012.

Jahn, A. and Holland, M. M.: Implications of Arctic sea ice changes for North Atlantic deep convection and the meridional overturning circulation in CCSM4-CMIP5 simulations, Geophys. Res. Lett., 40, 1206-1211, https://doi.org/10.1002/grl.50183, 2013.

Jungclaus, J. H., Lohmann, K., and Zanchettin, D.: Enhanced 20thcentury heat transfer to the Arctic simulated in the context of climate variations over the last millennium, Clim. Past, 10, 22012213, https://doi.org/10.5194/cp-10-2201-2014, 2014.

King, M. D., Howat, I. M., Jeong, S., Noh, M. J., Wouters, B., Noël, B., and van den Broeke, M. R.: Seasonal to decadal variability in ice discharge from the Greenland Ice Sheet, The Cryosphere, 12, 3813-3825, https://doi.org/10.5194/tc-12-3813-2018, 2018.

Knutti, R., Rugenstein, M. A. A., and Hegerl, G. C.: Beyond equilibrium climate sensitivity, Nat. Geosci., 10, 727-736, https://doi.org/10.1038/ngeo3017, 2017.

Koven, C. D., Ringeval, B., Friedlingstein, P., Ciais, P., Cadule, P., Khvorostyanov, D., Krinner, G., and Tarnocai, C.: Permafrost carbon-climate feedbacks accelerate global warming, P. Natl. Acad. Sci. USA, 108, 14769-14774, https://doi.org/10.1073/pnas.1103910108, 2011.

Koven, C. D., Riley, W. J., and Stern, A.: Analysis of Permafrost Thermal Dynamics and Response to Climate Change in the CMIP5 Earth System Models, J. Climate, 26, 1877-1900, https://doi.org/10.1175/JCLI-D-12-00228.1, 2013.

Krakauer, N. Y., Puma, M. J., and Cook, B. I.: Impacts of soil-aquifer heat and water fluxes on simulated global climate, Hydrol. Earth Syst. Sci., 17, 1963-1974, https://doi.org/10.5194/hess-17-1963-2013, 2013.

Kuhlbrodt, T. and Gregory, J. M.: Ocean heat uptake and its consequences for the magnitude of sea level rise and climate change, Geophys. Res. Lett., 39, L18608, https://doi.org/10.1029/2012GL052952, 2012.

Kundzewicz, Z. W., Kanae, S., Seneviratne, S. I., Handmer, J., Nicholls, N., Peduzzi, P., Mechler, R., Bouwer, L. M., Arnell, N., Mach, K., Muir-Wood, R., Brakenridge, G. R., Kron, W., Benito, G., Honda, Y., Takahashi, K., and Sherstyukov, B.: Flood risk and climate change: global and regional perspectives, Hydrolog. Sci. J., 59, 1-28, https://doi.org/10.1080/02626667.2013.857411, 2014.

Levitus, S., Antonov, J., and Boyer, T.: Warming of the world ocean, 1955-2003, Geophys. Res. Lett., 32, L02604, https://doi.org/10.1029/2004GL021592, 2005.

Levitus, S., Antonov, J. I., Boyer, T. P., Baranova, O. K., Garcia, H. E., Locarnini, R. A., Mishonov, A. V., Reagan, J. R., Seidov, D., Yarosh, E. S., and Zweng, M. M.: World ocean heat content and thermosteric sea level change (0-2000 m), 1955-2010, Geophys. Res. Lett., 39, L10603, https://doi.org/10.1029/2012GL051106, 2012.

Levy, K., Woster, A. P., Goldstein, R. S., and Carlton, E. J.: Untangling the Impacts of Climate Change on Waterborne Diseases: a Systematic Review of Relationships between Diarrheal Diseases and Temperature, Rainfall, Flooding, and Drought, Environ. Sci. Technol., 50, 4905-4922, https://doi.org/10.1021/acs.est.5b06186, 2016.

Liepert, B. G. and Lo, F.: CMIP5 update of "Inter-model variability and biases of the global water cycle in CMIP3 coupled climate models", Environ. Res. Lett., 8, 029401, https://doi.org/10.1088/1748-9326/8/2/029401, 2013.

Lin, I. I., Goni, G. J., Knaff, J. A., Forbes, C., and Ali, M. M.: Ocean heat content for tropical cyclone intensity forecasting and its impact on storm surge, Nat. Hazards, 66, 1481-1500, https://doi.org/10.1007/s11069-012-0214-5, 2013.

LLNL: CMIP5 Data Description, available at: https: //pcmdi.llnl.gov/mips/cmip5/docs/standard_output.pdf?id=14 (last acess: May 2020), 2010.

Lloyd, S. J., Kovats, R. S., and Chalabi, Z.: Climate Change, Crop Yields, and Undernutrition: Development of a Model to Quantify the Impact of Climate Scenarios on Child Undernutrition, Environ. Health Persp., 119, 1817-1823, https://doi.org/10.1289/ehp.1003311, 2011.

Long, M. C., Lindsay, K., Peacock, S., Moore, J. K., and Doney, S. C.: Twentieth-Century Oceanic Carbon Uptake and Storage in CESM1(BGC), J. Climate, 26, 6775-6800, https://doi.org/10.1175/JCLI-D-12-00184.1, 2013. 
MacDougall, A. H., González-Rouco, J. F., Stevens, M. B., and Beltrami, H.: Quantification of subsurface heat storage in a GCM simulation, Geophys. Res. Lett., 35, L13702, https://doi.org/10.1029/2008GL034639, 2008.

MacDougall, A. H., Avis, C. A., and Weaver, A. J.: Significant contribution to climate warming from the permafrost carbon feedback, Nat. Geosci., 5, 719-721, https://doi.org/10.1038/ngeo1573, 2012.

Mainelli, M., DeMaria, M., Shay, L. K., and Goni, G.: Application of Oceanic Heat Content Estimation to Operational Forecasting of Recent Atlantic Category 5 Hurricanes, Weather Forecast., 23, 3-16, https://doi.org/10.1175/2007WAF2006111.1, 2008.

Marsh, D. R., Mills, M. J., Kinnison, D. E., Lamarque, J.-F., Calvo, N., and Polvani, L. M.: Climate Change from 1850 to 2005 Simulated in CESM1(WACCM), J. Climate, 26, 7372-7391, https://doi.org/10.1175/JCLI-D-12-00558.1, 2013.

Matthews, T. K. R., Wilby, R. L., and Murphy, C.: Communicating the deadly consequences of global warming for human heat stress, P. Natl. Acad. Sci. USA, 114, 3861-3866, https://doi.org/10.1073/pnas.1617526114, 2017.

McDougall, T. J.: Potential Enthalpy: A Conservative Oceanic Variable for Evaluating Heat Content and Heat Fluxes, J. Phys. Oceanogr., 33, 945-963, https://doi.org/10.1175/15200485(2003)033<0945:PEACOV>2.0.CO;2, 2003.

McDougall, T. J., Jackett, D. R., Wright, D. G., and Feistel, R.: Accurate and Computationally Efficient Algorithms for Potential Temperature and Density of Seawater, J. Atmos. Ocean. Tech., 20, 730-741, https://doi.org/10.1175/15200426(2003)20<730:AACEAF>2.0.CO;2, 2003.

McGranahan, G., Balk, D., and Anderson, B.: The rising tide: assessing the risks of climate change and human settlements in low elevation coastal zones, Environ. Urban., 19, 17-37, https://doi.org/10.1177/0956247807076960, 2007.

McGuire, A. D., Lawrence, D. M., Koven, C., Clein, J. S., Burke, E., Chen, G., Jafarov, E., MacDougall, A. H., Marchenko, S., Nicolsky, D., Peng, S., Rinke, A., Ciais, P., Gouttevin, I., Hayes, D. J., Ji, D., Krinner, G., Moore, J. C., Romanovsky, V., Schädel, C., Schaefer, K., Schuur, E. A. G., and Zhuang, Q.: Dependence of the evolution of carbon dynamics in the northern permafrost region on the trajectory of climate change, P. Natl. Acad. Sci. USA, 115, 3882-3887, https://doi.org/10.1073/pnas.1719903115, 2018.

McMichael, A. J., Woodruff, R. E., and Hales, S.: Climate change and human health: present and future risks, Lancet, 367, 859869, https://doi.org/10.1016/S0140-6736(06)68079-3, 2006.

McPherson, M., García-García, A., Cuesta-Valero, F. J., Beltrami, H., Hansen-Ketchum, P., MacDougall, D., and Ogden, N. H.: Expansion of the Lyme Disease Vector Ixodes Scapularis in Canada Inferred from CMIP5 Climate Projections, Environ. Health Persp., 125, 057008, https://doi.org/10.1289/EHP57, 2017.

Meehl, G. A., Washington, W. M., Arblaster, J. M., Hu, A., Teng, H., Kay, J. E., Gettelman, A., Lawrence, D. M., Sanderson, B. M., and Strand, W. G.: Climate Change Projections in CESM1(CAM5) Compared to CCSM4, J. Climate, 26, 62876308, https://doi.org/10.1175/JCLI-D-12-00572.1, 2013.

Meehl, G. A., Senior, C. A., Eyring, V., Flato, G., Lamarque, J.-F., Stouffer, R. J., Taylor, K. E., and Schlund, M.: Context for interpreting equilibrium climate sensitivity and transient climate response from the CMIP6 Earth system models, Sci. Adv., 6, eaba1981, https://doi.org/10.1126/sciadv.aba1981, 2020.

Melton, J. R. and Arora, V. K.: Sub-grid scale representation of vegetation in global land surface schemes: implications for estimation of the terrestrial carbon sink, Biogeosciences, 11, 10211036, https://doi.org/10.5194/bg-11-1021-2014, 2014.

Meredith, M., Sommerkorn, M., Cassotta, S., Derksen, C., Ekaykin, A., Hollowed, A., Kofinas, G., Mackintosh, A., MelbourneThomas, J., Muelbert, M., Ottersen, G., Pritchard, H., and Schuur, E.: Polar Regions, in: IPCC Special Report on the Ocean and Cryosphere in a Changing Climate, edited by: Pörtner, H.-O., Roberts, D., Masson-Delmotte, V., Zhai, P., Tignor, M., Poloczanska, E., Mintenbeck, K., Alegría, A., Nicolai, M., Okem, A., Petzold, J., Rama, B., and Weyer, N., in press, available at: https://www.ipcc.ch/site/assets/uploads/sites/3/2019/11/ 07_SROCC_Ch03_FINAL.pdf (last access: 3 May 2021), 2019.

Mieville, A., Granier, C., Liousse, C., Guillaume, B., Mouillot, F., Lamarque, J.-F., Grégoire, J.-M., and Pétron, G.: Emissions of gases and particles from biomass burning during the 20th century using satellite data and an historical reconstruction, Atmos. Environ., 44, 1469-1477, https://doi.org/10.1016/j.atmosenv.2010.01.011, 2010.

Miller, R. L., Schmidt, G. A., Nazarenko, L. S., Tausnev, N., Bauer, S. E., DelGenio, A. D., Kelley, M., Lo, K. K., Ruedy, R., Shindell, D. T., Aleinov, I., Bauer, M., Bleck, R., Canuto, V., Chen, Y., Cheng, Y., Clune, T. L., Faluvegi, G., Hansen, J. E., Healy, R. J., Kiang, N. Y., Koch, D., Lacis, A. A., LeGrande, A. N., Lerner, J., Menon, S., Oinas, V., Pérez García-Pando, C., Perlwitz, J. P., Puma, M. J., Rind, D., Romanou, A., Russell, G. L., Sato, M., Sun, S., Tsigaridis, K., Unger, N., Voulgarakis, A., Yao, M.-S., and Zhang, J.: CMIP5 historical simulations (1850-2012) with GISS ModelE2, J. Adv. Model. Earth Syst., 6, 441-477, https://doi.org/10.1002/2013MS000266, 2014.

Nowicki, S. M. J., Payne, A., Larour, E., Seroussi, H., Goelzer, H., Lipscomb, W., Gregory, J., Abe-Ouchi, A., and Shepherd, A.: Ice Sheet Model Intercomparison Project (ISMIP6) contribution to CMIP6, Geosci. Model Dev., 9, 4521-4545, https://doi.org/10.5194/gmd-9-4521-2016, 2016.

Oleson, K. W., Lawrence, D. M., Bonan, G. B., Flanner, E. K., Lawrence, P. J., Levis, S., Swenson, S. C., Thornton, P. E., Dai, A., Decker, M., Dickinson, R., Feddema, J., Heald, C. L., Hoffman, F., Lamarque, J.-F., Mahowald, N., Niu, G.-Y., Qian, T., Randerson, J., Running, S., Sakaguchi, K., Slater, A., Stockli, R., Wang, A., Yang, Z.-L., Zeng, X., and Zeng, X.: Technical description of version 4.0 of the Community Land Model (CLM), Tech. Rep., Technical Note NCAR/TN-478+STR, National Center for Atmospheric Research - NCAR, Boulder, Colorado, USA, 2010.

Oppenheimer, M., Glavovic, B., Hinkel, J., van de Wal, R., Magnan, A., Abd-Elgawad, A., Cai, R., Cifuentes-Jara, M., DeConto, R., Ghosh, T., Hay, J., Isla, F., Marzeion, B., Meyssignac, B., and Sebesvari, Z.: Sea Level Rise and Implications for Low-Lying Islands, Coasts and Communities, in: IPCC Special Report on the Ocean and Cryosphere in a Changing Climate, edited by: Pörtner, H.-O., Roberts, D., Masson-Delmotte, V., Zhai, P., Tignor, M., Poloczanska, E., Mintenbeck, K., Alegría, A., Nicolai, M., Okem, A., Petzold, J., Rama, B., and Weyer, N., in press, available at: https://www.ipcc.ch/site/assets/uploads/sites/3/2019/11/ 08_SROCC_Ch04_FINAL.pdf (last access: 3 May 2021), 2019. 
Palmer, M. D. and McNeall, D. J.: Internal variability of Earth's energy budget simulated by CMIP5 climate models, Environ. Res. Lett., 9, 034016, https://doi.org/10.1088/1748-9326/9/3/034016, 2014.

Palmer, M. D., McNeall, D. J., and Dunstone, N. J.: Importance of the deep ocean for estimating decadal changes in Earth's radiation balance, Geophys. Res. Lett., 38, L13707, https://doi.org/10.1029/2011GL047835, 2011.

Pan, Y., Li, L., Jiang, X., Li, G., Zhang, W., Wang, X., and Ingersoll, A. P.: Earth's changing global atmospheric energy cycle in response to climate change, Nat. Commun., 8, 14367, https://doi.org/10.1038/ncomms14367, 2017.

Patz, J. A., Gibbs, H. K., Foley, J. A., Rogers, J. V., and Smith, K. R.: Climate Change and Global Health: Quantifying a Growing Ethical Crisis, EcoHealth, 4, 397-405, https://doi.org/10.1007/s10393-007-0141-1, 2007.

Pendergrass, A. G. and Hartmann, D. L.: The Atmospheric Energy Constraint on Global-Mean Precipitation Change, J. Climate, 27, 757-768, https://doi.org/10.1175/JCLI-D-13-00163.1, 2014a.

Pendergrass, A. G. and Hartmann, D. L.: Changes in the Distribution of Rain Frequency and Intensity in Response to Global Warming, J. Climate, 27, 8372-8383, https://doi.org/10.1175/JCLI-D-14-00183.1, 2014b.

Phalkey, R. K., Aranda-Jan, C., Marx, S., Höfle, B., and Sauerborn, R.: Systematic review of current efforts to quantify the impacts of climate change on undernutrition, P. Natl. Acad. Sci. USA, 112, 4522-4529, https://doi.org/10.1073/pnas.1409769112, 2015.

Previdi, M., Smith, K. L., and Polvani, L. M.: How Well Do the CMIP5 Models Simulate the Antarctic Atmospheric Energy Budget?, J. Climate, 28, 7933-7942, https://doi.org/10.1175/JCLI-D-15-0027.1, 2015.

Rhein, M., Rintoul, S., Aoki, S., Campos, E., Chambers, D., Feely, R., Gulev, S., Johnson, G., Josey, S., Kostianoy, A., Mauritzen, C., Roemmich, D., Talley, L., and Wang, F.: Observations: Ocean, in: Climate Change 2013: The Physical Science Basis, Contribution of Working Group I to the Fifth Assessment Report of the Intergovernmental Panel on Climate Change, edited by: Stocker, T., Qin, D., Plattner, G.-K., Tignor, M., Allen, S., Boschung, J., Nauels, A., Xia, Y., Bex, V., and Midgley, P., Cambridge University Press, Cambridge, UK and New York, USA, 255-316, https://doi.org/10.1017/CBO9781107415324.010, 2013.

Rignot, E., Mouginot, J., Scheuchl, B., van den Broeke, M., van Wessem, M. J., and Morlighem, M.: Four decades of Antarctic Ice Sheet mass balance from 1979-2017, P. Natl. Acad. Sci. USA, 116, 1095-1103, https://doi.org/10.1073/pnas.1812883116, 2019.

Rosenzweig, C., Elliott, J., Deryng, D., Ruane, A. C., Müller, C., Arneth, A., Boote, K. J., Folberth, C., Glotter, M., Khabarov, N., Neumann, K., Piontek, F., Pugh, T. A. M., Schmid, E., Stehfest, E., Yang, H., and Jones, J. W.: Assessing agricultural risks of climate change in the 21 st century in a global gridded crop model intercomparison, P. Natl. Acad. Sci. USA, 111, 32683273, https://doi.org/10.1073/pnas.1222463110, 2014.

Schädel, C., Schuur, E. A. G., Bracho, R., Elberling, B., Knoblauch, C., Lee, H., Luo, Y., Shaver, G. R., and Turetsky, M. R.: Circumpolar assessment of permafrost $\mathrm{C}$ quality and its vulnerability over time using long-term incubation data, Global Change Biol., 20, 641-652, https://doi.org/10.1111/gcb.12417, 2014.
Schuur, E. A. G., McGuire, A. D., Schädel, C., Grosse, G., Harden, J. W., Hayes, D. J., Hugelius, G., Koven, C. D., Kuhry, P., Lawrence, D. M., Natali, S. M., Olefeldt, D., Romanovsky, V. E., Schaefer, K., Turetsky, M. R., Treat, C. C., and Vonk, J. E.: Climate change and the permafrost carbon feedback, Nature, 520, 171-179, https://doi.org/10.1038/nature14338, 2015.

Schweiger, A. J., Wood, K. R., and Zhang, J.: Arctic Sea Ice Volume Variability over 1901-2010: A Model-Based Reconstruction, J. Climate, 32, 4731-4752, https://doi.org/10.1175/JCLI-D19-0008.1, 2019.

Scoccimarro, E., Gualdi, S., Bellucci, A., Sanna, A., Giuseppe Fogli, P., Manzini, E., Vichi, M., Oddo, P., and Navarra, A.: Effects of Tropical Cyclones on Ocean Heat Transport in a High-Resolution Coupled General Circulation Model, J. Climate, 24, 4368-4384, https://doi.org/10.1175/2011JCLI4104.1, 2011.

Séférian, R., Gehlen, M., Bopp, L., Resplandy, L., Orr, J. C., Marti, O., Dunne, J. P., Christian, J. R., Doney, S. C., Ilyina, T., Lindsay, K., Halloran, P. R., Heinze, C., Segschneider, J., Tjiputra, J., Aumont, O., and Romanou, A.: Inconsistent strategies to spin up models in CMIP5: implications for ocean biogeochemical model performance assessment, Geosci. Model Dev., 9, 1827 1851, https://doi.org/10.5194/gmd-9-1827-2016, 2016.

Sen Gupta, A., Jourdain, N. C., Brown, J. N., and Monselesan, D.: Climate Drift in the CMIP5 Models, J. Climate, 26, 8597-8615, https://doi.org/10.1175/JCLI-D-12-00521.1, 2013.

Sherwood, S. C. and Huber, M.: An adaptability limit to climate change due to heat stress, P. Natl. Acad. Sci. USA, 107, 95529555, https://doi.org/10.1073/pnas.0913352107, 2010.

Smeed, D. A., Josey, S. A., Beaulieu, C., Johns, W. E., Moat, B. I., Frajka-Williams, E., Rayner, D., Meinen, C. S., Baringer, M. O., Bryden, H. L., and McCarthy, G. D.: The North Atlantic Ocean Is in a State of Reduced Overturning, Geophys. Res. Lett., 45, 1527-1533, https://doi.org/10.1002/2017GL076350, 2018.

Smith, C. J., Kramer, R. J., Myhre, G., Alterskjær, K., Collins, W., Sima, A., Boucher, O., Dufresne, J.-L., Nabat, P., Michou, M., Yukimoto, S., Cole, J., Paynter, D., Shiogama, H., O’Connor, F. M., Robertson, E., Wiltshire, A., Andrews, T., Hannay, C., Miller, R., Nazarenko, L., Kirkevåg, A., Olivié, D., Fiedler, S., Lewinschal, A., Mackallah, C., Dix, M., Pincus, R., and Forster, P. M.: Effective radiative forcing and adjustments in CMIP6 models, Atmos. Chem. Phys., 20, 9591-9618, https://doi.org/10.5194/acp-20-9591-2020, 2020.

Smith, D. M., Allan, R. P., Coward, A. C., Eade, R., Hyder, P., Liu, C., Loeb, N. G., Palmer, M. D., Roberts, C. D., and Scaife, A. A.: Earth's energy imbalance since 1960 in observations and CMIP5 models, Geophys. Res. Lett., 42, 1205-1213, https://doi.org/10.1002/2014GL062669, 2015.

Smith, R., Jones, P., Briegleb, B., Bryan, F., Danabasoglu, G., Dennis, J., Dukowicz, J., Eden, C., Fox-Kemper, B., Gent, P., Hecht, M., Jayne, S., Jochum, M., Large, W., Lindsay, K., Maltrud, M., Norton, N., Peacock, S., Vertenstein, M., and Yeager, S.: The Parallel Ocean Program (POP) Reference Manual, Ocean Component of the Community Climate System Model (CCSM) and Community Earth System Model (CESM), Tech. Rep., LAUR01853, National Center for Atmospheric Research, Boulder, Colorado, USA, 2010. 
Soong, J. L., Phillips, C. L., Ledna, C., Koven, C. D., and Torn, M. S.: CMIP5 Models Predict Rapid and Deep Soil Warming Over the 21st Century, J. Geophys. Res.-Biogeo., 125, e2019JG005266, https://doi.org/10.1029/2019JG005266, 2020.

Steiner, A. K., Ladstädter, F., Randel, W. J., Maycock, A. C., Fu, Q., Claud, C., Gleisner, H., Haimberger, L., Ho, S.-P., Keckhut, P., Leblanc, T., Mears, C., Polvani, L. M., Santer, B. D., Schmidt, T., Sofieva, V., Wing, R., and Zou, C.-Z.: Observed Temperature Changes in the Troposphere and Stratosphere from 1979 to 2018, J. Climate, 33, 8165-8194, https://doi.org/10.1175/JCLI-D-190998.1, 2020.

Stevens, M. B., Smerdon, J. E., González-Rouco, J. F., Stieglitz, M., and Beltrami, H.: Effects of bottom boundary placement on subsurface heat storage: Implications for climate model simulations, Geophys. Res. Lett., 34, L02702, https://doi.org/10.1029/2006GL028546, 2007.

Taylor, K. E., Stouffer, R. J., and Meehl, G. A.: An Overview of CMIP5 and the Experiment Design, B. Am. Meteorol. Soc., 93, 485-498, https://doi.org/10.1175/BAMS-D-11-00094.1, 2011.

Tjiputra, J. F., Roelandt, C., Bentsen, M., Lawrence, D. M., Lorentzen, T., Schwinger, J., Seland, Ø., and Heinze, C.: Evaluation of the carbon cycle components in the Norwegian Earth System Model (NorESM), Geosci. Model Dev., 6, 301-325, https://doi.org/10.5194/gmd-6-301-2013, 2013.

Trenberth, K. E.: Using Atmospheric Budgets as a Constraint on Surface Fluxes, J. Climate, 10, 2796-2809, https://doi.org/10.1175/15200442(1997)010<2796:UABAAC>2.0.CO;2, 1997.

Trenberth, K. E., Fasullo, J. T., and Balmaseda, M. A.: Earth's Energy Imbalance, J. Climate, 27, 3129-3144, https://doi.org/10.1175/JCLI-D-13-00294.1, 2014.

Trenberth, K. E., Fasullo, J. T., von Schuckmann, K., and Cheng, L.: Insights into Earth's Energy Imbalance from Multiple Sources, J. Climate, 29, 7495-7505, https://doi.org/10.1175/JCLI-D-160339.1, 2016.

Trenberth, K. E., Cheng, L., Jacobs, P., Zhang, Y., and Fasullo, J.: Hurricane Harvey Links to Ocean Heat Content and Climate Change Adaptation, Earth's Future, 6, 730-744, https://doi.org/10.1029/2018EF000825, 2018.

Van Wijk, W. R., Borghrst, A. J. W., Businger, J. A., Derksen, W. J., Schmidt, F. H., Scholte Ubing, D. W., and De Vries, D. A.: Physics of Plant Environment, North-Holland Publishing Company, Amsterdam, the Netherlands, 1963.

Vaughan, D., Comiso, J., Allison, I., Carrasco, J., Kaser, G., Kwok, R., Mote, P., Murray, T., Paul, F., Ren, J., Rignot, E., Solomina, O., Steffen, K., and Zhang, T.: Observations: Cryosphere, in: Climate Change 2013: The Physical Science Basis, Contribution of Working Group I to the Fifth Assessment Report of the Intergovernmental Panel on Climate Change, edited by: Stocker, T., Qin, D., Plattner, G.-K., Tignor, M., Allen, S., Boschung, J., Nauels, A., Xia, Y., Bex, V., and Midgley, P., Cambridge University Press, Cambridge, UK and New York, USA, 317-382, https://doi.org/10.1017/CBO9781107415324.012, 2013.

Volodin, E., Dianskii, N., and Gusev, A.: Simulating present-day climate with the INMCM4.0 coupled model of the atmospheric and oceanic general circulations, Izv. Atmos. Ocean. Phy.+, 46, 414-431, https://doi.org/10.1134/S000143381004002X, 2010. von Schuckmann, K., Palmer, M. D., Trenberth, K. E., Cazenave, A., Chambers, D., Champollion, N., Hansen, J., Josey, S. A., Loeb, N., Mathieu, P. P., Meyssignac, B., and Wild, M.: An imperative to monitor Earth's energy imbalance, Nat. Clim. Change, 6, 138-144, https://doi.org/10.1038/nclimate2876, 2016.

von Schuckmann, K., Cheng, L., Palmer, M. D., Hansen, J., Tassone, C., Aich, V., Adusumilli, S., Beltrami, H., Boyer, T., Cuesta-Valero, F. J., Desbruyères, D., Domingues, C., García-García, A., Gentine, P., Gilson, J., Gorfer, M., Haimberger, L., Ishii, M., Johnson, G. C., Killick, R., King, B. A., Kirchengast, G., Kolodziejczyk, N., Lyman, J., Marzeion, B., Mayer, M., Monier, M., Monselesan, D. P., Purkey, S., Roemmich, D., Schweiger, A., Seneviratne, S. I., Shepherd, A., Slater, D. A., Steiner, A. K., Straneo, F., Timmermans, M.-L., and Wijffels, S. E.: Heat stored in the Earth system: where does the energy go?, Earth Syst. Sci. Data, 12, 2013-2041, https://doi.org/10.5194/essd-12-2013-2020, 2020.

Wada, A. and Chan, J. C. L.: Relationship between typhoon activity and upper ocean heat content, Geophys. Res. Lett., 35, L17603, https://doi.org/10.1029/2008GL035129, 2008.

Watanabe, M., Suzuki, T., O'ishi, R., Komuro, Y., Watanabe, S., Emori, S., Takemura, T., Chikira, M., Ogura, T., Sekiguchi, M., Takata, K., Yamazaki, D., Yokohata, T., Nozawa, T., Hasumi, H., Tatebe, H., and Kimoto, M.: Improved Climate Simulation by MIROC5: Mean States, Variability, and Climate Sensitivity, J. Climate, 23, 6312-6335, https://doi.org/10.1175/2010JCLI3679.1, 2010.

Watanabe, S., Hajima, T., Sudo, K., Nagashima, T., Takemura, T., Okajima, H., Nozawa, T., Kawase, H., Abe, M., Yokohata, T., Ise, T., Sato, H., Kato, E., Takata, K., Emori, S., and Kawamiya, M.: MIROC-ESM 2010: model description and basic results of CMIP5-20c3m experiments, Geosci. Model Dev., 4, 845-872, https://doi.org/10.5194/gmd-4-845-2011, 2011.

WCRP: Coupled Model Intercomparison Project 5 (CMIP5), available at: https://esgf-node.llnl.gov/projects/cmip5/, last access: 3 May 2021.

Wild, M.: The global energy balance as represented in CMIP6 climate models, Clim. Dynam., 55, 553-577, https://doi.org/10.1007/s00382-020-05282-7, 2020.

Wu, T., Song, L., Li, W., Wang, Z., Zhang, H., Xin, X., Zhang, Y., Zhang, L., Li, J., Wu, F., Liu, Y., Zhang, F., Shi, X., Chu, M., Zhang, J., Fang, Y., Wang, F., Lu, Y., Liu, X., Wei, M., Liu, Q., Zhou, W., Dong, M., Zhao, Q., Ji, J., Li, L., and Zhou, M.: An overview of BCC climate system model development and application for climate change studies, J. Meteorol. Res.-PRC, 28, 34-56, https://doi.org/10.1007/s13351-014-3041-7, 2014.

$\mathrm{Wu}, \mathrm{X}$. Lu, Y., Zhou, S., Chen, L., and Xu, B.: Impact of climate change on human infectious diseases: Empirical evidence and human adaptation, Environ. Int., 86, 14-23, https://doi.org/10.1016/j.envint.2015.09.007, 2016.

Yukimoto, S., Adachi, Y., Hosaka, M., Sakami, T., Yoshimura, H., Hirabara, M., Tanaka, T. Y., Shindo, E., Tsujino, H., Deushi, M., Mizuta, R., Yabu, S., Obata, A., Nakano, H., Koshiro, T., Ose, T., and Kitoh, A.: A New Global Climate Model of the Meteorological Research Institute: MRI-CGCM - Model Description and Basic Performance, J. Meteorol. Soc. Jpn., 90A, 23-64, https://doi.org/10.2151/jmsj.2012-A02, 2012. 
Zemp, M., Huss, M., Thibert, E., Eckert, N., McNabb, R., Huber, J., Barandun, M., Machguth, H., Nussbaumer, S. U., GärtnerRoer, I., Thomson, L., Paul, F., Maussion, F., Kutuzov, S., and Cogley, J. G.: Global glacier mass changes and their contributions to sea-level rise from 1961 to 2016, Nature, 568, 382-386, https://doi.org/10.1038/s41586-019-1071-0, 2019.
Zhang, J. and Rothrock, D. A.: Modeling Global Sea Ice with a Thickness and Enthalpy Distribution Model in Generalized Curvilinear Coordinates, Mon. Weather Rev., 131, 845-861, https://doi.org/10.1175/15200493(2003)131<0845:MGSIWA>2.0.CO;2, 2003. 